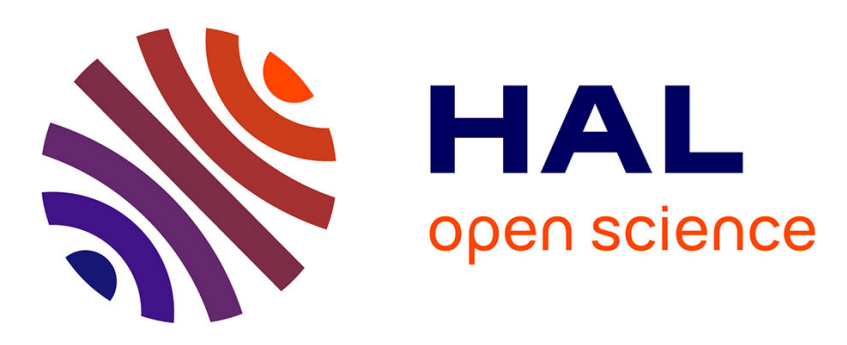

\title{
New relative sea-level insights into the isostatic history of the Western Mediterranean
}

Matteo Vacchi, Matthieu Ghilardi, Rita T Melis, Giorgio Spada, Matthieu

Giaime, Nick Marriner, Thomas Lorscheid, Christophe Morhange, Francesc

Burjachs, Alessio Rovere

\section{To cite this version:}

Matteo Vacchi, Matthieu Ghilardi, Rita T Melis, Giorgio Spada, Matthieu Giaime, et al.. New relative sea-level insights into the isostatic history of the Western Mediterranean. Quaternary Science Reviews, 2018, 201, pp.396-408. 10.1016/j.quascirev.2018.10.025 . hal-02091058

\section{HAL Id: hal-02091058 \\ https://hal.science/hal-02091058}

Submitted on 13 Jan 2022

HAL is a multi-disciplinary open access archive for the deposit and dissemination of scientific research documents, whether they are published or not. The documents may come from teaching and research institutions in France or abroad, or from public or private research centers.
L'archive ouverte pluridisciplinaire HAL, est destinée au dépôt et à la diffusion de documents scientifiques de niveau recherche, publiés ou non, émanant des établissements d'enseignement et de recherche français ou étrangers, des laboratoires publics ou privés. 


\title{
New relative sea-level insights into the isostatic history of the Western Mediterranean
}

\author{
Matteo Vacchi ${ }^{12^{*}}$, Matthieu Ghilardi ${ }^{3}$, Rita T. Melis ${ }^{4}$, Giorgio Spada $^{5}$, Matthieu Giaime ${ }^{6}$, Nick Marriner ${ }^{7}$, Thomas \\ Lorscheid $^{8}$, Christophe Morhange ${ }^{3}$, Francesc Burjachs9,10,11 and Alessio Rovere ${ }^{8}$.
}

(1)

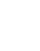

\author{
${ }^{1}$ Geography, College of Life and Environmental Sciences, University of Exeter, EX4 4RJ, Exeter, UK \\ ${ }^{2}$ Dipartimento di Scienze della Terra, Università di Pisa, Via S. Maria, 53, 56126 Pisa, Italy \\ ${ }^{3}$ Aix-Marseille Université, CNRS-CEREGE, UMR 7330, IRD, Collège de France, INRA Aix en Provence, France \\ ${ }^{4}$ Dipartimento Scienze Chimiche e Geologiche, Università degli Studi di Cagliari, Via Trentino 51, 09127 Cagliari, Italy \\ ${ }^{5}$ Università degli Studi di Urbino, Dipartimento di Scienze Pure ed Applicate (DiSPeA), Urbino, Italy \\ ${ }^{6}$ Department of Geography, Durham University, South Road, Durham, DH1 3LE, UK \\ ${ }^{7}$ CNRS Chrono-Environnement UMR6249, Université de Franche-Comté, UFR ST, Besançon, France \\ ${ }^{8}$ University of Bremen, Marum, ZMT, D-28359, Bremen, Germany \\ ${ }^{9}$ ICREA, Barcelona, Catalonia, Spain. \\ ${ }^{10}$ IPHES, Institut Català de Paleoecologia Humana i Evolució Social. Campus Sescelades URV Tarragona, Catalonia, Spain. \\ ${ }^{11}$ URV, Àrea de Prehistòria, Universitat Rovira i Virgili. 43002 Tarragona, Catalonia, Spain. \\ *m.vacchi@exeter.ac.uk
}

\section{(1)}

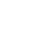

\section{Abstract}

A recent suite of Relative Sea-Level (RSL) data for the past $12 \mathrm{ka} \mathrm{BP}$ have provided new insights into the sea-level histories of the western Mediterranean region. Our analysis of the chronostratigraphic context of sea-level indicators from Spain (Catalonia, Balearic Islands and Gulf of Valencia), France (Corsica Island) and Italy (Sardinia Island) has yielded 163 new sea-level index and limiting points. These data have considerably enhanced previous RSL compilations, in addition to improving the quality of spatio-temporal sea-level reconstructions and our capacity to estimate isostatic-related vertical motions in the western Mediterranean basin. The glacial and hydro-isostatic adjustment (GIA) pattern elucidated by the new 1 database shows discrepancy with respect to those predicted by the available GIA models. In particular, the 
new results underscore a non-coherent isostatic response of the central portion of the western Mediterranean, with the Balearic Islands manifesting significant departures from the sea-level histories of Corsica, Sardinia and, more generally, along most of the western Mediterranean coast. Our results are a crucial contribution to defining both the pattern and the magnitude of the isostatic signal along the western Mediterranean coast. In fact, vertical isostatic motions represent a key to better assess any possible post-industrial acceleration in sealevel rise and to define future scenarios of coastal inundation in the context of global change.

\section{Keywords}

Sea-level changes; isostatic adjustment; vertical crustal motion; Holocene; Mediterranean Sea

\section{Introduction}

Understanding how changing ice volumes have contributed to sea-level rise in the past can provide insights into the sensitivity of ice sheets to future warmer conditions, and constrain physical models used to project ice-sheet response to future climate change (e.g., Kopp et al., 2009; Dutton et al., 2015; Purcell et al., 2016). Glacial and hydro-isostatic adjustment (GIA) constitutes an important driver of past, present and future sealevel variability (e.g. Milne et al., 2009; Gehrels et al., 2011; Khan et al., 2015). For this reason, a major focus of current sea-level research is the continuous improvement of GIA geophysical models in an attempt to provide more accurate constraints for future sea-level scenarios (e.g. Nicholls et al., 2014; Goldberg et al., 2016; Roy and Peltier, 2018). Our understanding of current rates of sea-level rise from tide gauges or satellite data (e.g. Church and White, 2006; Cazenave et al., 2014; Bonaduce et al., 2016) requires correction for GIA effects that can be quantified using observations of former sea levels (e.g. Kemp et al., 2009; Engelhart et al., 2011; Rovere et al., 2016). Holocene (i.e. the last 12.0 ka BP) Relative Sea-Level (RSL) reconstructions have frequently been used to test and calibrate GIA models over timescales longer than the instrumental record (e.g., Shennan and Horton, 2002; Engelhart et al., 2011, Bradley et al., 2016; Edwards et al., 2017; Khan et al., 2017).

58 According to published geophysical models (e.g. Lambeck and Purcell, 2005; Stocchi and Spada, 2007;

59 2009; Lambeck et al., 2011; Roy and Peltier, 2018), GIA-related deformation in the Western Mediterranean 
60 is mainly controlled by water loading, which has resulted in widespread subsidence throughout much of the

61 basin at an average rate of RSL rise of $\sim 1 \mathrm{~mm} \mathrm{a}^{-1}$ over the last 6000 years. Such models were tuned with

RSL data from several areas, particularly from the Italian coast (e.g., Lambeck et al., 2004; 2011; Antonioli et al., 2009) and the western Mediterranean (Vacchi et al., 2016). However, due to its complex tectonic setting (e.g., Ferranti et al., 2006; Faccenna et al., 2014), RSL histories from the Mediterranean Sea are often reported as being influenced by the Holocene activity of major faults (e.g., Stiros et al., 2000, Mastronuzzi and Sansò, 2002, Scicchitano et al., 2011). This has often hampered the identification of the GIA component in the RSL record. This issue is even more complex in those coastal regions located at the mouth of major Mediterranean rivers (e.g., Amorosi et al., 1999; 2013; Vella et al., 2005; Marriner et al., 2012a), where the RSL record is strongly affected by long-term subsidence induced by sediment loading and compaction. The aim of this study is to improve the quality of spatio-temporal sea-level reconstructions along a large portion of the Mediterranean coast of Spain (Catalonia coast, Balearic Islands and Gulf of Valencia, figure contribution (e.g., Lambeck and Purcell, 2004; Stocchi et al., 2007; Roy and Peltier, 2018). In all the five suite of SLIPs and RSL limiting points following the protocol described by the International Geoscience Programme (IGCP) projects 61, 200, 495 and 588 (e.g., Preuss, 1979; van de Plassche, 1982; Gehrels and Long, 2007; Shennan et al., 2015). We subsequently compared the reconstructed RSL histories with the predictions based on the ICE-6G (VM5a) GIA model (Peltier et al., 2015) to visualize and discuss the spatiotemporal variability of the isostatic response in the Western Mediterranean. 
The study area encompasses a large portion of the Western Mediterranean basin, at latitudes between $\sim 39.0^{\circ}$ $\mathrm{N}$ and $\sim 43.0^{\circ} \mathrm{N}$ and longitudes between $\sim-0.5^{\circ} \mathrm{E}$ and $\sim 9.5^{\circ} \mathrm{E}$ (figure 1). The area is characterized by a microtidal regime, with tidal ranges typically not exceeding $0.45 \mathrm{~m}$ (Tsimplis et al., 1995). The long record of historical seismicity, coupled with on-going crustal deformation, contributed to define the neotectonic framework of the Western Mediterranean (e.g. Faccenna et al., 2004; Serpelloni et al., 2007; Noquet, 2012). Two small oceanic basins (the Tyrrhenian and the Liguro-Provençal back-arc basins) lie on the Nubia-Eurasia convergent margin and are separated by the Corsica-Sardinia rigid continental block (e.g. Vernant et al., 2010; Faccenna et al., 2014). Some parts of the back-arc basin margins are undergoing active compressional tectonics along the east-Alboran, Algerian, and south-Tyrrhenian margins (Billi et al., 2011; Serpelloni et al., 2013). The south-Tyrrhenian compressional domain extends to northeast Sicily, while the Tyrrhenian side of the Calabrian Arc and central-southern Apennines are dominated by extension (figure 1; e.g., Ferranti et al., 2006; Faccenna et al., 2014). In these coastal areas, a major tectonic influence on the Holocene RSL evolution has often been reported (e.g., Ferranti et al., 2010; Scicchitano et al., 2011). By contrast, tectonic stability characterizes much of the Tyrrhenian and Liguro-Provençal basin (e.g. Ferranti et al., 2006; Billi et al., 2011, Nocquet, 2012). All of the coastal sectors discussed in this paper lie within areas characterised by a minimal or negligible tectonic influence on the late-Quaternary RSL evolution (e.g., Ferranti et al., 2006; Lorscheid et al., 2017; Stocchi et al., 2018). Absence of historical seismicity characterizes much of the Spanish regions included in the database (regions 1, 2 and 3, figure 1). One possible exception is the Valencia coastal plain, where weak seismic activity $(<5.0 \mathrm{M})$ is reported (Olivera et al., 1992; Anzidei et al., 2014). Both Corsica (France) and Sardinia (Italy) (regions 4 and 5, figure 1) are widely acknowledged to be amongst the most tectonically stable areas of the Mediterranean, with the

111 negligible vertical motions during the last $\sim 125 \mathrm{ka} \mathrm{BP}$ according to the present elevation of the last 112 interglacial shoreline.

\section{3. Previous sea-level compilations and recent sources of the RSL datapoints}


115 A review of the available RSL data at the Western Mediterranean scale (Vacchi et al., 2016) allowed us to

116 constrain coastal areas where Holocene RSL histories were conflicting, of low quality or almost non-

117 existent. For the Catalonia coast, extending along the northernmost portion of the Spanish Mediterranean

118 coast (region 1, figure 1), previous data included beachrock samples and lagoonal data, the current positions

119 of which have been significantly affected by sediment compaction, especially during the mid to late-

120 Holocene (Somoza et al., 1998, Roqué Pau and Pallí Buxó, 1997; Gámez Torrent, 2007; Vacchi et al., 2016).

121 Recent investigations on the Barcelona and Empúries coastal plains (Daura et al., 2016; Ejarque et al., 2016),

122 in the Ebro Delta (Cearreta et al., 2016) and on remains of seagrass palaeo-soils (Posidonia oceanica mats,

123 López-Merino et al., 2017) provided useful new data to help to evaluate the RSL history of the area. The

124 Vacchi et al. (2016) review did not include a Holocene RSL curve for the Balearic Islands (region 2, figure

125 1). This was mainly due to the very limited amount of RSL data in the area. However, recent investigations

126 performed in Mallorca and Menorca (Burjachs et al., 2017, Giaime et al., 2017) coupled with the sparse

127 older data (Fornós et al., 1998, Yll et al., 1999) allowed us to comprehensively reassess the RSL history of

128 this insular complex.

129 Vacchi et al. (2016) underlined the poor quality of the RSL reconstruction for the Gulf of Valencia (region 3,

130 figure 1). Large uncertainties are associated with the SLIPs and poor descriptions of the original data did not

131 allow us to robustly assess the RSL history in this area, notably for the last 6000 years. A new dataset of 132 dated estuarine facies (Carmona et al., 2016; Blázquez et al., 2017; Rodríguez-Pérez, 2018) has facilitated a

133 significant advance in the definition of the mid- to late-Holocene RSL evolution of this coastal sector.

134 RSL histories in Corsica (region 4) show some inconsistencies (Vacchi et al., 2016). Fossil fixed biological

135 indicators sampled on the northern coast of the island (Laborel et al., 1994) indicate that RSL variations 136 during the last $\sim 4.0 \mathrm{ka}$ BP did not exceed $\sim 2 \mathrm{~m}$ (Vacchi et al., 2016); these data are in agreement with the 137 new RSL dataset produced by Vacchi et al. (2017) for the eastern coast of Corsica. Conversely, data obtained 138 from a series of submerged beachrocks in the Bonifacio Strait (i.e. the narrow strait dividing Corsica and 139 Sardinia, see figure 4, Nesteroff, 1984; De Muro and Orrù, 1998; Lambeck et al., 2004) show a significant 140 departure from the above-mentioned data, with an offset of up to $-3 \mathrm{~m}$, especially for the mid to late-

141 Holocene (Vacchi et al., 2017). Such a discrepancy is difficult to explain in terms of the tectonic setting (see 142 section 2) or compaction-related subsidence (Vacchi et al., 2016). In this database, we tried to resolve these 
144 performed in several Corsican coastal marshes and lagoons (Currás et al., 2017; Ghilardi et al., 2017a,b;

145 Poher et al., 2017; Vacchi et al., 2017).

146 Sardinia (region 5) has been widely investigated and several types of sea-level data have been used to infer 147 the RSL evolution (De Muro and Orrù, 1998; Orrù et al., 2004; 2011; 2014; Pirazzoli, 2005; Antonioli et al., 148 2007, 2012; De Falco et al., 2015). These data mainly constrain the late-Holocene RSL evolution.

149 Conversely, a larger scatter is present in the early to mid-Holocene data. This is essentially related to 150 compaction (such as in the Cagliari coastal plain, Antonioli et al., 2007) or beachrock dating problems 151 (Vacchi et al., 2016; 2017). Sardinia has also been the object of recent investigations (Melis et al., 2017, 2018; Palombo et al., 2017; Pascucci et al., 2018; Ruiz et al, 2018), mainly focused on multiproxy palaeoenvironmental reconstructions, yielding new sea-level data in these coastal areas.

\section{Production of RSL datapoints}

\subsection{RSL index and limiting points}

Most of the SLIPs (cf. Shennan et al., 2015; Hijma et al., 2015) in the database are derived from cores in coastal and alluvial plains, coastal marshes and lagoons. In particular, lagoons (i.e. low-energy inland waterbodies that are either intermittently or continuously connected to the open sea) are very common geomorphological features on clastic Mediterranean coasts (e.g., Di Rita et al., 2011; Salel et al., 2016;

161 Fontana et al., 2017). Here, water depth very seldom exceeds a few meters (e.g., Marco-Barba et al., 2013;

162 Di Rita and Melis, 2013) and samples collected in lagoonal facies have often been used to assess the palaeo 163 sea-level position (e.g., Primavera et al., 2011; Sander et al., 2015; 2016; Vacchi et al., 2017).

164 In this study, we produced SLIPs from sedimentary records following the recent protocol developed for the Mediterranean (Vacchi et al., 2016, table 1). This methodology has recently been applied to a number of studies focused on Mediterranean RSL reconstructions (e.g., Fontana et al., 2017; Karkani et al., 2017, 2018;

167 Melis et al., 2017, 2018; Ruello et al., 2017; Vacchi et al., 2017, Ghilardi et al., 2018, Kaniewsky et al., 168 2018). The definition of the depositional facies was based on a biostratigraphic basis and, in particular, on 169 the macro-and micro-faunal assemblages (i.e., malacofauna, foraminifera and ostracod assemblages, e.g., 
Rossi et al., 2011; Marriner et al., 2012b; 2014). The detailed description of the indicative meaning

171 associated with the different depositional facies (table 1) is provided in Vacchi et al., (2016).

172 We subsequently added to the database beachrocks, fixed biological and archaeological SLIPs already

173 present in previous RSL reconstructions for the area (Lambeck et al., 2011; Vacchi et al., 2016).

174 All samples that did not show a clear and robustly established relationship with the MSL were converted into

175 limiting points (Engelhart et al., 2015; Vacchi et al., 2016). These data are extremely important in

176 constraining the RSL position above or below a reconstructed elevation. Reconstructed RSL points must fall

177 below terrestrial limiting points and above marine limiting points (e.g. Engelhart and Horton, 2012; Vacchi

178 et al., 2014). In this database, marine limiting points are typically from samples deposited in the infralittoral

179 zone and from interlaced roots and rhizomes of the marine seagrass Posidonia oceanica (known as matte,

180 López-Merino et al., 2017). Terrestrial limiting points are typically samples deposited in freshwater

181 swamps, fluvial environments and upper beach/foreshore deposits (table 1). Furthermore, we considered

182 terrestrial limiting points those archaeological indicators that were theoretically above the MSL at the time of 183 their functioning period, such as tombs and burials (Auriemma and Solinas, 2009).

\subsection{Altitude of the RSL data points}

For each dated SLIP, RSL is estimated by the following equation:

$\mathrm{RSL}_{\mathrm{i}}=\mathrm{A}_{\mathrm{i}}-\mathrm{RWL}_{\mathrm{i}}$

190 (Shennan and Horton, 2002), where $\mathrm{A}_{\mathrm{i}}$ is the altitude and $\mathrm{RWL}_{\mathrm{i}}$ is the reference water level of sample $\mathrm{i}$, both 191 expressed relative to the same datum; i.e. MSL in our analysis.

193 The total vertical uncertainty on $\mathrm{RSL}_{\mathrm{i}}$ is mainly represented by the indicative range and by the elevation 194 error (Shennan and Horton, 2002). In the database presented here, the latter range from $\pm 0.05 \mathrm{~m}$ for sample 195 altitudes measured using high-precision survey methods (e.g., differential GPS) to $\pm 0.5 \mathrm{~m}$ when the altitude 196 was estimated using Digital Elevation Models, such as the sites of Torregrande and Posada in Sardinia 197 (Melis et al., 2017, 2018). 
In line with Hijma et al. (2015), we also considered and corrected for the following potential sources of

additional vertical uncertainties: (1) a core stretching/shortening error ( $\pm 0.15 \mathrm{~m}$ for rotary corers and

vibracorers to $\pm 0.05 \mathrm{~m}$ for hand coring), (2) a sample thickness uncertainty (3) an angle of borehole

uncertainty, as a function of the overburden of the sample, taken in this study to be $1 \%$, and (4) an

environmental uncertainty of $0.5 \mathrm{~m}$ for those samples deposited in undifferentiated brackish environments

203 (Vacchi et al., 2016, see section 4.1). Due to the microtidal setting of the research area and lack of specific

204 regional studies, we did not include an uncertainty term for potential changes in the palaeo-tidal range.

205 We subdivided the SLIPs into intercalated and basal categories (Horton and Shennan, 2009). Intercalated samples are those recovered from organic horizons located between clastic layers and, therefore, are subject to compaction (e.g., Hijma et al., 2015). Basal lagoonal samples are recovered from sedimentary units overlying incompressible substrates (rocky basements or a thick layer of coarse sand or gravel) and are therefore less prone to compaction. Virtually incompressible samples are also the fossil remains of fixed

210 biological indicators, represented by fossil rims of Lithophyllum byssoides (Laborel et al., 1994; Vacchi et 211 al., 2016) and beachrock samples (Mauz et al., 2015).

\subsection{Chronology of sea-level data points}

214 The age of the samples was estimated using radiocarbon $\left({ }^{14} \mathrm{C}\right)$ dating of peat layers, organic material, wood, 215 plant remains, seagrass remains and marine shells. Radiocarbon ages were calibrated into sidereal years with 216 a $2 \sigma$ range. All SLIPs are presented as calibrated years before present (BP), where year 0 is AD 1950

217 (Stuiver and Polach, 1977) and were calibrated using CALIB 7.1. We employed the IntCal13 and Marine13

218 (Reimer et al., 2013) datasets for terrestrial and marine samples, respectively. Where available, local 219 reservoir corrections were taken from either the Marine Reservoir Database (Reimer and Reimer, 2001) or 220 from other published values. In calibrating the samples of organic sediment, we assumed that the original 221 depositional environment was a transitional zone in the back-coastal area, influenced by fluvial processes as 222 well as marine inputs. Therefore, for sediment dates where the percentage of marine carbon was available 223 (Melis et al., 2017, 2018) a mixed IntCal13/Marine13 calibration method was applied (Di Rita et al. 2011, Di 224 Rita and Melis, 2013). 
225 A concern with old radiocarbon ages is the correction for isotopic fractionation (Törnqvist et al., 2015) that

226 became a standard procedure at most laboratories by the mid-1980s (Hijma et al. 2015). In the database, the 227 majority of samples were dated after 1990 and, therefore, most are not subject to this potential source of 228 error. For the seven ages that are affected, we followed the procedure described by Hijma et al. (2015) to 229 correct for isotopic fractionation.

\section{Prediction of RSL}

The RSL calculations presented herein have been performed using the Sea Level Equation solver SELEN (https://geodynamics.org/cig/software/selen/). The program, which was first introduced by Spada and Stocchi (2007) adopting the classical GIA theory of Farrell and Clark (1976), has now been improved and includes the rotational feedbacks on sea level, according to the method outlined by Milne and Mitrovica (1998). Furthermore, following the generalised Sea Level Equation theory described by Mitrovica and Milne (2003), our calculations fully account for the horizontal migration of the shorelines, for the transition from grounded to floating ice and for time variations of the ocean function in response to sea-level variations. In our GIA runs, we adopted the recent ICE-6G_C chronology (Peltier et al., 2015), and the mantle rheological profile VM5a. The Sea Level Equation is solved to harmonic degree 256, on a global equal area grid with spacing of $\sim 20 \mathrm{~km}$.

\section{Results}

244 We assessed 169 new radiocarbon-dated RSL data points collected in the western Mediterranean Sea. We 245 combined these new data with 78 RSL data reported in Vacchi et al. (2016). We then reconstructed the RSL 246 histories of the 5 regions using a database comprising 165 SLIPs and 70 limiting points (appendix A). 12 247 data points were rejected because of i) dating problems (i.e., Bonifacio Strait beachrocks, Vacchi et al., 248 2017) and anomalous $\delta^{13} \mathrm{C}(\%)$ values of the sample, ii) difficulties in the definition of the indicative 249 meaning and iii) discrepancies in the measurements of the altitude of archaeological structures.

250 The newly produced RSL data points (163 SLIPs and limiting points) constitute $\sim 68 \%$ of the present 251 database; the number of SLIPs (figure 2A) was increased by $\sim 58 \%$ with respect to the Vacchi et al. (2016) 252 compilation. It has engendered a significant improvement in the assessment of the RSL histories of the 
253 Western Mediterranean. The age range of the new data spans the last $\sim 12.0 \mathrm{ka}$ BP (figure $2 \mathrm{~A}$ ), with a

254 considerable increase in the number of SLIPs, notably for the mid to late-Holocene (figure 2B).

\subsection{Catalonia coast (Region 1)}

In region 1, we improved the RSL history with 15 SLIPs and 19 terrestrial limiting points spanning the last

$\sim 6$ ka BP (figure 3). These data, coupled with the previously available SLIPs, facilitate the reconstruction of the RSL history for the last $\sim 6 \mathrm{ka} \mathrm{BP.} \mathrm{A} \mathrm{suite} \mathrm{of} \mathrm{early-Holocene} \mathrm{SLIPs} \mathrm{documents} \mathrm{a} \mathrm{rapid} \mathrm{rise} \mathrm{in} \mathrm{RSL} \mathrm{from} \mathrm{-}$ $40 \pm 0.8 \mathrm{~m}$ at $\sim 12.0 \mathrm{ka}$ BP to $-12.3 \pm 0.7 \mathrm{~m} \sim 8.4 \mathrm{ka} \mathrm{BP}$. In the mid-Holocene, there is a significant discrepancy between the new data and some of the older SLIPs (figure 3). However, two basal SLIPs robustly place the RSL position at $\sim-3.0 \mathrm{~m}$ at $\sim 5.8 \mathrm{ka}$ BP. RSL rose slowly to $-2.6 \pm 0.5 \mathrm{~m}$ at $\sim 4.6 \mathrm{ka} \mathrm{BP}$ and at $-0.8 \pm 0.6 \mathrm{~m}$ at $\sim 2.0 \mathrm{ka} \mathrm{BP}$. In the last $1.5 \mathrm{ka} \mathrm{BP}$ the total RSL variation was $-0.1 \pm 0.6 \mathrm{~m}$.

\subsection{Balearic Islands (Region 2)}

The RSL record for region 2 includes 27 SLIPs and 7 limiting points (figure 3). They constrain $\sim 9.5 \mathrm{ka} \mathrm{BP}$ of RSL evolution in an area lacking any previous sea-level reconstructions. A suite of marine limiting points constrains the RSL to above $\sim-21 \mathrm{~m}$ at $\sim 9.5 \mathrm{ka} \mathrm{BP}$, above $\sim-11.5 \mathrm{~m}$ at $\sim 8.4 \mathrm{ka}$ BP and above $\sim-10.8 \mathrm{~m}$ at $\sim 8.0 \mathrm{ka}$ BP. The oldest SLIP indicates that RSL was at $-6.9 \pm 0.8 \mathrm{~m}$ at $\sim 7.9 \mathrm{ka} \mathrm{BP}$, followed by a continuous rising rate which brought the RSL to $-3.6 \pm 0.8 \mathrm{~m}$ at $\sim 7.2 \mathrm{ka} \mathrm{BP}$ and to $-1.5 \pm 0.8 \mathrm{~m}$ at $\sim 6.0 \mathrm{ka} \mathrm{BP}$ when a SLIP places RSL at $-1.5 \pm 0.8 \mathrm{~m}$. Since that period, the rising trend has slowed dramatically, with total RSL variation being within $1.7 \mathrm{~m}$ during the last $5.3 \mathrm{ka}$ BP. Younger SLIPs place the RSL at $-0.5 \pm 1 \mathrm{~m}$ at $\sim 3.5 \mathrm{ka}$

\subsection{Gulf of Valencia (Region 3)}

In region 3, we improved the RSL record with 12 SLIPs and 5 limiting points spanning the last $\sim 8.2 \mathrm{ka}$

277 (figure 3). These new data, added to the previously available ones, allow us to assess the RSL history for the 278 last $\sim 9.1 \mathrm{ka} \mathrm{BP}$, when the oldest SLIP places the RSL at $-16.1 \pm 0.6 \mathrm{~m}$ (figure 3). RSL rose rapidly to $-10.6 \pm$ $2790.6 \mathrm{~m}$ at $\sim 8.7 \mathrm{ka} \mathrm{BP}$, to $-4.6 \pm 0.5 \mathrm{~m}$ at $\sim 8.2 \mathrm{ka} \mathrm{BP}$ and to $-2.1 \pm 0.3$ at $\sim 7.5 \mathrm{ka} \mathrm{BP}$. Despite significant scatter, younger RSL data clearly show a significant deceleration in the rising trend. At $\sim 4.8 \mathrm{ka} B P$, one SLIP places 
the RSL at $-0.9 \pm 0.3 \mathrm{~m}$ while the remaining data are consistent with total RSL variation not exceeding $1 \mathrm{~m}$ in the late-Holocene period (figure 3).

\subsection{Corsica Island (Region 4)}

In region 4, we improved the RSL record with 27 SLIPs and 16 limiting points spanning the last $5.4 \mathrm{ka}$ BP (figure 4). These data, merged with the previously available ones, constrain a RSL history that spans the last $\sim 8.8 \mathrm{ka} \mathrm{BP}$ (figure 4). The oldest SLIPs are both beachrocks and document a progressive RSL rise from $17.5 \pm 1.6 \mathrm{~m}$ at $8.8 \mathrm{ka}$ BP to $-3.8 \pm 0.8 \mathrm{~m}$ at $\sim 5.4 \mathrm{ka}$ BP. One younger lagoonal SLIP places the RSL at $-1.4 \pm$ $1.0 \mathrm{~m}$ at $\sim 4.6 \mathrm{ka}$ BP. Since this period, the RSL is robustly constrained with the new SLIPs (mainly from lagoonal samples) that are in very good agreement with the previously available Lithophyllum byssoides SLIPs. At $\sim 4.5$ and $3.5 \mathrm{ka} \mathrm{BP}$, RSL was at $-1.77 \pm 0.5$ and $-1.1 \pm 0.3 \mathrm{~m}$, respectively. RSL rose slowly to $0.8 \pm 0.3 \mathrm{~m}$ at $\sim 2.1 \mathrm{ka} \mathrm{BP}$ and the total RSL variation in the last $\sim 1.6 \mathrm{ka} \mathrm{BP}$ was within $\sim 0.7 \mathrm{~m}$.

\subsection{Sardinia Island (Region 5)}

In region 5, we improved the RSL record with 17 SLIPs and 18 limiting points spanning the last $\sim 7.7 \mathrm{ka} \mathrm{BP}$. These data, merged with previously available ones, shed new light on a RSL history covering the last $\sim 11 \mathrm{ka}$ BP (figure 4). A suite of basal and beachrocks SLIPs documents the rapid RSL rise of the early-Holocene from $-45.5 \pm 1.6 \mathrm{~m}$ at $\sim 10.8 \mathrm{ka}$ BP to $-27 \pm 1.1 \mathrm{~m}$ at $\sim 9.4 \mathrm{ka}$ BP. At the beginning of the mid-Holocene, two basal SLIPs place the RSL at $-8.2 \pm 1.2$ and at $-7.4 \pm 1.2 \mathrm{~m}$ at $\sim 7.7$ and $\sim 7.5 \mathrm{ka} \mathrm{BP}$, respectively. These data are only partly in agreement with two terrestrial limiting points derived from Neolithic burials ( 7.3 ka BP) found in the Grotta Verde cave. In fact, a first limiting point constrains the RSL below - $8 \mathrm{~m}$ while a second one constrains the RSL $\sim 2 \mathrm{~m}$ deeper (below -10 m, Figure 4). The subsequent mid-Holocene RSL evolution is constrained by a suite of SLIPs placing RSL at $-4.4 \pm 0.8 \mathrm{~m}$ at $\sim 6.0 \mathrm{ka} \mathrm{BP}$, at $-3.6 \pm 0.8 \mathrm{~m}$ at $\sim 5.6 \mathrm{ka} \mathrm{BP}$ and finally at $-2.2 \pm 1.1 \mathrm{~m}$ at $\sim 4.6 \mathrm{ka}$ BP. The new mid-Holocene dataset shows significant discrepancy with respect to the previously available SLIPs, mainly represented by the lagoonal samples from the Gulf of Cagliari and the beachrocks found in the northern sector of the Island (figure 4). 
the RSL above $-1.1 \pm 0.2 \mathrm{~m}$, in agreement with a slightly younger ( 2.5 ka BP) SLIP that places the RSL at -

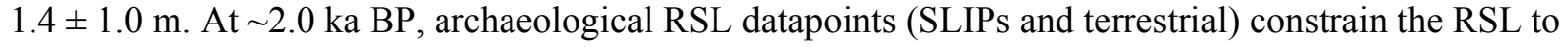

311 between -0.6 and $-1.4 \mathrm{~m}$ while a younger SLIP places the RSL at $-0.3 \pm 1.1 \mathrm{~m}$ at $\sim 1.3 \mathrm{ka} \mathrm{BP}$.

\section{Discussion}

314 The main result of our work is a new compilation of RSL data that significantly improves the reconstruction

315 of RSL histories for five Western Mediterranean regions that were previously characterized by either a

316 paucity of data or conflicting records (Vacchi et al., 2016). The newly assembled database therefore

317 constitutes an essential benchmark to evaluate RSL patterns in the western Mediterranean Sea.

318 In effect, sediment compaction significantly influenced previous RSL reconstructions, such as those recorded 319 in the Ebro and Llobregat deltas (Somoza et al., 1998; Gámez Torrent, 2007) and the Cagliari coastal plain 320 (Orrù et al., 2004; Antonioli et al., 2007). Moreover, dating problems associated with old beachrock samples

321 from sites located between Corsica and Sardinia (figure 4, Bonifacio Strait, Nesteroff, 1984; De Muro and 322 Orrù, 1998) led to poor constraints on RSL evolution, notably for the mid to late-Holocene (Vacchi et al., 323 2017).

324 The newly assembled RSL record clearly shows a rapid rise in the early-Holocene ( 12.0 to $\sim 8.0 \mathrm{ka} \mathrm{BP})$ 325 followed by a sudden slowdown in the rates of RSL rise in the mid-Holocene ( 7.5 and $\sim 4.0 \mathrm{ka} \mathrm{BP})$ and, 326 finally, by minimal changes during the late-Holocene (since $\sim 4.0 \mathrm{ka} \mathrm{BP}$ ). This sudden reduction in the rising 327 rates closely mirrors the final phase of the North America deglaciation ( 7.0 ka BP; Lambeck et al., 2014).

328 This Holocene sea-level behaviour is in agreement with the pattern previously reported along the tectonically 329 stable coasts of the Western Mediterranean (Vacchi et al., 2016).

330 The new record from Catalonia shows agreement with the ICE-6G (VM5a) GIA model and is comparable, 331 within errors, to the reconstructed RSL histories of the French Mediterranean coast and northwest Italy 332 (Vacchi et al., 2016). This suggests minimal variations in the isostatic pattern over much of the northern 333 coast of the western Mediterranean.

334 Similarly, the ICE-6G (VM5a) model shows agreement with the data from Corsica and Sardinia, where the 335 expanded RSL record allowed us to resolve conflicting data and to improve our ability to quantify the 
maximum isostatic contribution in the western Mediterranean basin by very significantly increasing the number of SLIPs for the last $\sim 8.0 \mathrm{ka} \mathrm{BP}$ (see details in section 7.1).

By contrast, the model underestimates the RSL position in both the Gulf of Valencia and in the Balearic Islands, especially for the mid-Holocene. However, the RSL record from Valencia cannot be considered as an ideal setting for testing GIA models, because the area is potentially affected by land-level changes related to historical seismicity (Olivera et al., 1992; Anzidei et al., 2014). Moreover, GPS vertical velocities document a general subsidence trend $\left(\leq 2 \mathrm{~mm} \mathrm{a}^{-1}\right)$, especially for the Valencia coastal plains (Serpelloni et al., 2013), where most of the data were collected. For this reason, the RSL record from Valencia should be used with caution because post-depositional vertical changes (either positive or negative) may have affected the current elevation of the SLIPs and limiting points. The Balearic Islands are located far from the Mediterranean's major tectonic boundaries (Faccenna et al., 2014; Devoti et al., 2017) and have been affected by negligible historical seismicity (Nocquet, 2012) and by minimal vertical motions during the last $\sim 125 \mathrm{ka} \mathrm{BP}$ (Dorale et al., 2010; Stocchi et al., 2018). Here, the fit between the ICE-6G (VM5a) GIA model and the geological RSL data does not appear to be completely satisfactory, especially with regards to the mid-Holocene. This raises intriguing questions and issues potentially related to GIA processes that we address in section 7.2.

\subsection{New insights into the RSL evolution of Corsica and Sardinia}

354 A variety of geophysical models (Lambeck and Purcell, 2005; Stocchi and Spada, 2007; Roy and Peltier, 2018) predict maximum GIA-related subsidence in the centre of the western Mediterranean basin and notably along the coasts of Sardinia. This assumption was questioned by Pirazzoli (2005), who, for the last two millennia, suggested a general overestimation of the predicted isostatic signal in this area. In a more recent analysis, Antonioli et al. (2007) and subsequently Lambeck et al. (2011) improved the knowledge of the RSL evolution of Sardinia by combining previously available data (Lambeck et al., 2004) with a number of archaeological RSL indicators spanning the last $2.5 \mathrm{ka}$.

361 These coastal archaeological structures, mainly comprising coastal quarries, harbour structures and tombs 362 provided new points to reconstruct the RSL history of Sardinia, representing a minimal limit for the RSL position (i.e., terrestrial limiting points, Auriemma and Solinas, 2009; Morhange and Marriner, 2015). These 
data, coupled with the new SLIPs included in the present database are not consistent with a negligible RSL

variation in the last $2.0 \mathrm{ka} \mathrm{BP}$ as indicated by Pirazzoli (2005). Specifically, they are consistent with a RSL

change greater than $\sim 0.8 \mathrm{~m}$ in the last $\sim 2.3 \mathrm{ka} \mathrm{BP}$ (Phoenician tomb found at $\sim-0.76 \mathrm{~m} \mathrm{MSL}$; Antonioli et al., 2007). Unfortunately, the large vertical uncertainties of the new Sardinian SLIPs do not help to significantly improve the quality of the late-Holocene RSL history.

369 Conversely, the new dataset for Corsica robustly corroborates the previous RSL reconstructions (Laborel et

dataset for Corsica suggests a relatively uniform GIA-related subsidence pattern for the whole island, with rates of $\sim 0.4 \mathrm{~mm} \mathrm{a}^{-1}$ during the last $4.0 \mathrm{ka}$. Even if the magnitudes are different, current GIA models (e.g., Stocchi and Spada, 2009; Lambeck et al., 2011; Roy and Peltier, 2018) predict an increase in GIA subsidence rates from Corsica to Sardinia. Unfortunately, the lack of robust SLIPs for Sardinia during the last $4.0 \mathrm{ka} \mathrm{BP}$ hampers a proper assessment of this assumption, and additional investigations are therefore required to improve understanding of the local late-Holocene RSL history.

By contrast, the new dataset for Sardinia has yielded new information to assess the mid-Holocene RSL evolution of the area. As stated in the introduction, the previously available data were mainly based on lagoonal samples from the Cagliari plain (probably effected by compaction, Antonioli et al., 2007) and on the last $\sim 7.5 \mathrm{ka}$ BP. This is concomitant with the Neolithic burials ( $\sim 7.3 \mathrm{ka} \mathrm{BP})$ found at $\sim-8.5 \mathrm{~m}$ in the beachrock samples mostly collected in the Bonifacio strait (Nesteroff, 1984, De Muro and Orrù, 1998), which are potentially affected by apparent younger ages related to problems in the radiometric dating of bulk cement more than 30 years ago (Vacchi et al., 2017). The new lagoonal SLIPs, collected from both the eastern and the western coasts of the island, show a significant departure from the data previously available for the Sardinian coast. In fact, the new dataset is consistent with a RSL variation that did not exceed $\sim 9 \mathrm{~m}$ in Grotta Verde cave (Antonioli et al., 1996; 2012; Guillot, 1997), but conflicts with the coeval pottery found in the same cave at -10 to -11 m (Benjamin et al., 2017; Palombo et al., 2017). Exploration of this submerged cave dates back to the 1970s (Lo Schiavo, 1987) and it represents one of the oldest archaeological findings used to infer past sea level in the Mediterranean (Benjamin et al., 2017). However, considerable debris flow 
is reported along the flank of the cave and several ceramic fragments were found mixed within these debris down to $-22 \mathrm{~m}$ (Guillot, 1997). Furthermore, lack of information on the levelling tools adopted during the cave exploration makes difficult to properly assess the vertical uncertainty of these archaeological findings. The large number of SLIPs produced in this paper seems to suggest that the terrestrial limiting point found at -10 to -11 m may significantly underestimate the RSL position in the first portion of the mid-Holocene. However, new high-resolution mapping of archaeological findings and of the stratigraphic context of the Grotta Verde are imperative to shed fresh light on this important palaeo sea-level position.

\subsection{The Balearic Islands: an isostatic conundrum}

401 The new dataset from the Balearic Islands is interesting for an assessment of the GIA pattern within the Mediterranean basin. This is because the maximum GIA-related subsidence of the whole Western Mediterranean (with a magnitude comparable to Sardinia) is predicted in the Balearic region (Lambeck et al., 404 2004; Lambeck and Purcell, 2005; Stocchi and Spada, 2007; Roy and Peltier, 2018, figure 5B). However, 405 comparison with the Sardinia record shows clear discrepancies with the Balearic Islands, with the RSL 406 history in the latter plotting significantly above the first one. For instance, at $\sim 6.0 \mathrm{ka}, \mathrm{RSL}$ in the Balearic 407 Islands (figure 3) was at least $\sim 2 \mathrm{~m}$ higher than in Sardinia (figure 4).

408 As already discussed above, the Balearic Islands are considered to be amongst the most tectonically stable 409 areas of the Mediterranean (Fornós et al., 2002; Dorale et al., 2010; Sàbat et al., 2011). Thus, any possible 410 tectonic movement cannot account for the observed discrepancy that is most likely related to a differential

411 GIA response in this Mediterranean sector. The RSL history of this portion of the basin may thus represent 412 an unicuum in the western Mediterranean, for which the entire RSL variation in the last $\sim 6.0 \mathrm{ka}$ BP is within $413 \sim 2.5 \mathrm{~m}$. The new lagoonal data are in agreement with the RSL reconstruction proposed on the basis of 414 archaeological findings and submerged speleothems (Gràcia et al., 2003; Tuccimei et al., 2010) and provides 415 evidence that GIA-related subsidence for this sector of the Mediterranean basin was minimal.

416 In figure 5A, we compared the best estimates of RSL changes in the Balearic Islands with Sardinia, both 417 spanning the last $\sim 8.0 \mathrm{ka} \mathrm{BP}$. In these regions, a comparable GIA fingerprint is predicted by the available 418 models (Galassi and Spada, 2014, figure 5B). 
419 This comparison suggests a significant offset between the two RSL records, in conflict with the GIA model 420 predictions. Although these data need to be corroborated by additional RSL investigations, we remark that 421 understanding the causes of the departure of the Balearic record with respect to other regions in the database 422 is crucial in refining the geography of isostatic processes in the Mediterranean. This is, in turn, essential in 423 (i) defining future relative sea-level rise scenarios (e.g., Church and White, 2006; Love et al., 2016) and (ii) 424 testing the exportability of global GIA models (e.g., Roy and Peltier, 2018). Concerning the model 425 predictions, it should be noted that the GIA models currently employed to model RSL in the Mediterranean 426 Sea (Lambeck and Purcell, 2005; Stocchi and Spada, 2007, 2009; Roy and Peltier, 2018) are affected by a 427 major limitation - they do not take into account the lateral variations in mantle viscosity or in the thickness 428 of the lithosphere. From global calculations, we know that these may well affect the Earth's response to 429 deglaciation (e.g., Spada et al., 2006).

\section{Conclusions}

432 In this paper, we produced a new dataset of RSL index and limiting points for a number of Mediterranean 433 regions effected by minimal tectonic influence and where GIA was the major driver of RSL evolution, 434 notably for the last 8000 years. The isostatic pattern defined from newly assembled databases shows 435 significant disparity with respect to those predicted by present GIA models. In particular, the new data 436 outline a non-coherent isostatic response of the central portion of the western Mediterranean, with the 437 Balearic Islands manifesting significant departures from the RSL evolution recorded in Corsica and Sardinia. 438 The new data presented in this work are crucial in defining the maximum magnitude of GIA contribution 439 along the Mediterranean coast. Ongoing GIA-related vertical motions represent a key parameter to quantify 440 any possible post-industrial acceleration in RSL rise and to define future scenarios of coastal inundation in 441 the Mediterranean region.

\section{Acknowledgments}

444 This paper is dedicated to Paolo A. Pirazzoli (1939-2017), a pioneer of sea level research in the 445 Mediterranean Sea. This paper contributes to the MOPP-Medflood (INQUA CMP 1603P) and HOLSEA 446 (INQUA CMP 1601P) projects. Thanks are also due to the PALSEA 2 (PAGES/INQUA/WUN working 
group) and IGCP Project 639 communities for the fruitful discussions during the workshops. This work was

supported by the Institutional Strategy of the University of Bremen, funded by the German Excellence Initiative (ABPZuK-03/2014) and by ZMT, the Center for Tropical Marine Ecology. Finally, we thank the two anonymous reviewers for their comments that significantly improved the significance of the paper.

\section{References}

Amorosi, A., Bini, M., Giacomelli, S., Pappalardo, M., Ribecai, C., Rossi, V., Sammartino, I., Sarti, G. 2013. Middle to late Holocene environmental evolution of the Pisa coastal plain (Tuscany, Italy) and early human settlements. Quaternary International, 303, 93-106.

Amorosi, A., Colalongo, M. L., Fusco, F., Pasini, G., Fiorini, F. 1999. Glacio-eustatic control of continentalshallow marine cyclicity from late Quaternary deposits of the southeastern Po Plain, northern Italy.

Quaternary Research, 52(1), 1-13.

460 Antonioli, F., Anzidei, M., Lambeck, K., Auriemma, R., Gaddi, D., Furlani, S., Orru, P., Solinas, E.,

461 Gaspari, A., Karinja, S., Kovačić, V., Surace, L. 2007. Sea-level change during the Holocene in Sardinia and 462 in the northeastern Adriatic (central Mediterranean Sea) from archaeological and geomorphological data.

463 Quaternary Science Reviews, 26(19), 2463-2486.

464 Antonioli, F., Ferranti, L., Fontana, A., Amorosi, A., Bondesan, A., Braitenberg, C., Dutton, A., Fontolan, 465 G., Furlani, S., Lambeck, K., Mastronuzzi, G., Monaco, C., Spada, G., Stocchi, P. 2009. Holocene relative 466 sea-level changes and vertical movements along the Italian and Istrian coastlines. Quaternary International, 467 206(1), 102-133.

468 Antonioli, F., Ferranti, L., Lo Schiavo, F. 1996. The submerged Neolithic burials of the Grotta Verde at 469 Capo Caccia (Sardinia, Italy) implication for the Holocene sea-level rise. Memorie Descrittive del Servizio 470 Geologico Nazionale, 52, 290-312.

471 Antonioli, F., Orrù, P., Porqueddu, A., Solinas, E. 2012. Variazioni del livello marino in Sardegna durante 472 gli ultimi millenni sulla base di indicatori geo-archeologici costieri. L'Africa romana XIX, Sassari 2010, 473 Roma 2012, pp. 2963-2972.

474 Anzidei, M., Lambeck, K., Antonioli, F., Furlani, S., Mastronuzzi, G., Serpelloni, E., Vannucci, G. 2014. 475 Coastal structure, sea-level changes and vertical motion of the land in the Mediterranean. Geological 476 Society, London, Special Publications, 388(1), 453-479.

477 Auriemma, R., Solinas, E. 2009. Archaeological remains as sea level change markers: a review. Quaternary 478 International, 206(1), 134-146. 
Benjamin, J., Rovere, A., Fontana, A., Furlani, S., Vacchi, M., Inglis, R. H., Galili, E., Antonioli, F., Sivan, D., Miko, S., Mourtzas, N., Felja, I., Meredith-Williams, M., Goodman-Tchernov, B., Kolaiti, E., Anzidei, M., Gehrels, R. 2017. Late Quaternary sea-level changes and early human societies in the central and eastern Mediterranean Basin: An interdisciplinary review. Quaternary International, 449, 29-57.

Billi, A., Faccenna, C., Bellier, O., Minelli, L., Neri, G., Piromallo, C., Presti, D., Scrocca, D., Serpelloni, E. 2011. Recent tectonic reorganization of the Nubia-Eurasia convergent boundary heading for the closure of the western Mediterranean. Bulletin de la Société Géologique de France, 182(4), 279-303.

Blázquez, A. M., Rodríguez-Pérez, A., Torres, T., Ortiz, J. E. 2017. Evidence for Holocene sea level and climate change from Almenara marsh (western Mediterranean). Quaternary Research, 88(2), 206-222.

Bonaduce, A., Pinardi, N., Oddo, P., Spada, G., Larnicol, G. 2016. Sea-level variability in the Mediterranean Sea from altimetry and tide gauges. Climate Dynamics, 47(9-10), 2851-2866.

Bradley, S. L., Milne, G. A., Horton, B. P., Zong, Y. 2016. Modelling sea level data from China and MalayThailand to estimate Holocene ice-volume equivalent sea level change. Quaternary Science Reviews, 137, 54-68.

Burjachs, F., Pérez-Obiol, R., Picornell-Gelabert, L., Revelles, J., Servera-Vives, G., Expósito, I., Yll, E. I. 2017. Overview of environmental changes and human colonization in the Balearic Islands (Western Mediterranean) and their impacts on vegetation composition during the Holocene. Journal of Archaeological Science: Reports, 12, 845-859.

Caldara, M., Simone, O. 2005. Coastal changes in the eastern Tavoliere Plain (Apulia, Italy) during the Late Holocene: Natural or anthropic?. Quaternary Science Reviews, 24(18-19), 2137-2145.

Carboni, M. G., Bergamin, L., Di Bella, L., Iamundo, F., Pugliese, N. 2002. Palaeoecological evidences from foraminifers and ostracods on Late Quaternary sea-level changes in the Ombrone river plain (central Tyrrhenian coast, Italy). Geobios, 35, 40-50.

Carmona, P., Ruiz-Pérez, J. M., Blázquez, A. M., López-Belzunce, M., Riera, S., Orengo, H. 2016. Environmental evolution and mid-late Holocene climate events in the Valencia lagoon (Mediterranean coast of Spain). The Holocene, 26(11), 1750-1765.

Cearreta, A., Benito, X., Ibáñez, C., Trobajo, R., Giosan, L. 2016. Holocene palaeoenvironmental evolution of the Ebro Delta (Western Mediterranean Sea): Evidence for an early construction based on the benthic foraminiferal record. The Holocene, 26(9), 1438-1456.

Cazenave, A., Dieng, H. B., Meyssignac, B., Von Schuckmann, K., Decharme, B., Berthier, E. 2014. The rate of sea-level rise. Nature Climate Change, 4(5), 358-361. 
510 Church, J. A., White, N. J. 2006. A 20th century acceleration in global sea-level rise. Geophysical research

511 letters, 33(1).

512 Currás, A., Ghilardi, M., Peche-Quilichini, K., Fagel, N., Vacchi, M., Delanghe, D., Contreras, D., Vella, C., 513 Ottaviani, J. C. (2017). Reconstructing past landscapes of the eastern plain of Corsica (NW Mediterranean)

514 during the last 6000years based on molluscan, sedimentological and palynological analyses. Journal of 515 Archaeological Science: Reports, 12, 755-769.

516 Daura, J., Sanz, M., Ramos, J., Riera, S., Miras, Y., Allué, E., Picornell-Gelabert, L., López-Reyes, D., 517 Albert, R.M., Macià, L., Domènech, R., Martinell, J., Fornós, J.J., Julià, R. 2016. Palaeoenvironmental 518 record of the Cal Maurici wetland sediment archive in Barcelona (NE Iberian Peninsula) between c. 6000 519 and 4000 cal. yr BP. The Holocene, 26(7), 1020-1039.

520 De Falco, G., Antonioli, F., Fontolan, G., Presti, V. L., Simeone, S., Tonielli, R. 2015. Early cementation and 521 accommodation space dictate the evolution of an overstepping barrier system during the Holocene. Marine Geology, 369, 52-66.

De Muro, S., Orrù, P. 1998. Il contributo delle Beach-Rock nello studio della risalita del mare olocenico. Le Beach-Rock post-glaciali della Sardegna nord-orientale. Il Quaternario, 11(1), 19-39.

Devoti, R., D'Agostino, N., Serpelloni, E., Pietrantonio, G., Riguzzi, F., Avallone, A., Cavaliere, A., Cheloni, D., Cecere, G., D'Ambrosio, G., Franco, L., Selvaggi, G., Metois, M., Esposito, A., Sepe, V., Galvani, A., Anzidei, M. 2017. A Combined Velocity Field of the Mediterranean Region. Annals of Geophysics, 60(2), 0215.

529 Di Rita, F., Melis, R. T. 2013. The cultural landscape near the ancient city of Tharros (central West 530 Sardinia): vegetation changes and human impact. Journal of Archaeological Science, 40(12), 4271-4282.

531 Di Rita, F., Simone, O., Caldara, M., Gehrels, W. R., Magri, D. 2011. Holocene environmental changes in 532 the coastal Tavoliere Plain (Apulia, southern Italy): a multiproxy approach. Palaeogeography,

533 Palaeoclimatology, Palaeoecology, 310(3), 139-151.

534 Dorale, J. A., Onac, B. P., Fornós, J. J., Ginés, J., Ginés, A., Tuccimei, P., Peate, D. W. 2010. Sea-level 535 highstand 81,000 years ago in Mallorca. Science, 327(5967), 860-863.

536 Dutton, A., Webster, J. M., Zwartz, D., Lambeck, K., Wohlfarth, B. 2015. Tropical tales of polar ice: 537 evidence of Last Interglacial polar ice sheet retreat recorded by fossil reefs of the granitic Seychelles islands. 538 Quaternary Science Reviews, 107, 182-196.

539 Edwards, R., Gehrels, W. R., Brooks, A., Fyfe, R., Pullen, K., Kuchar, J., Craven, K. 2017. Resolving 540 discrepancies between field and modelled relative sea-level data: lessons from western Ireland. Journal of 541 Quaternary Science, 32(7), 957-975. 
543 a Mediterranean microtidal zone: Mid to Late Holocene natural dynamics and human management of the

544 Castelló lagoon, NE Spain. PloS one, 11(5), e0155446.

545 Engelhart, S. E., Horton, B. P. 2012. Holocene sea level database for the Atlantic coast of the United States.

546 Quaternary Science Reviews, 54, 12-25.

547 Engelhart, S. E., Horton, B. P., Douglas, B. C., Peltier, W. R., Törnqvist, T. E. 2009. Spatial variability of 548 late Holocene and 20th century sea-level rise along the Atlantic coast of the United States. Geology, 37(12), $549 \quad 1115-1118$.

550 Engelhart, S. E., Peltier, W. R., Horton, B. P. 2011. Holocene relative sea-level changes and glacial isostatic 551 adjustment of the US Atlantic coast. Geology, 39(8), 751-754.

552 Engelhart, S. E., Vacchi, M., Horton, B. P., Nelson, A. R., Kopp, R. E. 2015. A sea-level database for the 553 Pacific coast of central North America. Quaternary Science Reviews, 113, 78-92.

554 Faccenna, C., Becker, T. W., Auer, L., Billi, A., Boschi, L., Brun, J. P., Capitanio F., Funiciello, F., Horvat, 555 F., Jolivet L., Piromallo, C., Royden, L., Rossetti, F., Serpelloni, E. 2014. Mantle dynamics in the 556 Mediterranean. Reviews of Geophysics, 52(3), 283-332.

557 Faivre, S., Bakran-Petricioli, T., Horvatinčić, N., Sironić, A. 2013. Distinct phases of relative sea level 558 changes in the central Adriatic during the last 1500 years - influence of climatic variations?.

559 Palaeogeography, palaeoclimatology, palaeoecology, 369, 163-174.

560 Farrell, W., Clark, J., 1976. On postglacial sea-level. Geophysical Journal of Royal Astronomy Society 46, $561 \quad 647-667$.

562 Ferranti, L., Antonioli, F., Mauz, B., Amorosi, A., Dai Pra, G., Mastronuzzi, G., Monaco, C., Orru, P., 563 Pappalardo, M., Radtke, U., Renda, P., Romano., P., Sanso, P., Verrubbi, V. 2006. Markers of the last 564 interglacial sea-level high stand along the coast of Italy: tectonic implications. Quaternary international, 145, $56530-54$.

566 Fontana, A., Vinci, G., Tasca, G., Mozzi, P., Vacchi, M., Bivi, G., Rossatto, S., Salvador, L., Antonioli, F., 567 Asioli, A., Bresolin, M., Di Mario, F., Hajdas, I. 2017. Lagoonal settlements and relative sea level during 568 Bronze Age in Northern Adriatic: Geoarchaeological evidence and paleogeographic constraints. Quaternary 569 International, 439, 17-36.

570 Fornós, J. J., Gelabert, B., Ginés, A., Ginés, J., Tuccimei, P., Vesica, P. 2002. Phreatic overgrowths on 571 speleothems: a useful tool in structural geology in littoral karstic landscapes. The example of eastern 572 Mallorca (Balearic Islands). Geodinamica Acta, 15(2), 113-125. 
573 Galassi, G., Spada, G. 2014. Sea-level rise in the Mediterranean Sea by 2050: Roles of terrestrial ice melt,

574 steric effects and glacial isostatic adjustment. Global and Planetary Change, 123, 55-66.

575 Gámez Torrent D., 2007. Sequence Stratigraphy as a tool for water resources management in alluvial coastal 576 aquifers: application to the Llobregat delta (Barcelona, Spain), Ph'D Thesis, Technical University of 577 Catalonia, Barcelona, pp. 177.

578 Gehrels, W. R., Dawson, D. A., Shaw, J., Marshall, W. A. 2011. Using Holocene relative sea-level data to 579 inform future sea-level predictions: An example from southwest England. Global and Planetary Change, $580 \quad 78(3), 116-126$.

581 Gehrels, W.R., Long, A.J., 2007. Quaternary land-ocean interactions: sea-level change, sediments and 582 tsunami. Marine Geology 242, 169-190.

583 Ghilardi, M., Delanghe, D., Demory, F., Leandri, F., Pêche-Quilichini, K., Vacchi, M., Vella, M.A., Rossi, 584 V., Robresco, S. 2017a. Enregistrements d'événements extrêmes et évolution des paysages dans les basses 585 vallées fluviales du Taravo et du Sagone (Corse occidentale, France) au cours de l'âge du Bronze moyen à 586 final: une perspective géoarchéologique. Géomorphologie: relief, processus, environnement, 23(1), 15-35.

587 Ghilardi, M., Istria, D., Curras, A., Vacchi, M., Contreras, D., Vella, C., Dussouillez, P., Crest, Y., Guiter, F., 588 Delanghe, D. 2017b. Reconstructing the landscape evolution and the human occupation of the Lower Sagone 589 River (Western Corsica, France) from the Bronze Age to the Medieval period. Journal of Archaeological 590 Science: Reports, 12, 741-754.

591 Ghilardi, M., Vacchiu, M., Curràa, A., Muller Celka S., Theurillat, T., Lemos, I., Pavlopoulos, K., 2018. 592 Geoarchaeology of coastal landscape along the south Euboean Gulf (Euboea Island, Greece, during the 593 Holocene. Quaternaire 29 (2), 95-120

594 Giaime, M., Morhange, C., Ontiveros, M. Á. C., Fornós, J. J., Vacchi, M., Marriner, N. 2017. In search of 595 Pollentia's southern harbour: Geoarchaeological evidence from the Bay of Alcúdia (Mallorca, Spain).

596 Palaeogeography, Palaeoclimatology, Palaeoecology, 466, 184-201.

597 Goldberg, S. L., Lau, H. C., Mitrovica, J. X., Latychev, K. 2016. The timing of the Black Sea flood event: 598 Insights from modeling of glacial isostatic adjustment. Earth and Planetary Science Letters, 452, 178-184.

599 Gràcia, F., Jaume, D., Ramis, D., Fornós, J.J., Bover, P., Clamor, B., Gual, M.A., Vadell, M. 2003. Les 600 coves de Cala Anguila (Manacor, Mallorca). II: La Cova Genovesa o Cova d'en Bessó. Espeleogènesi, 601 geomorfologia, hidrologia, sedimentologia, fauna, paleontologia, arqueologia i conservació. Endins 25: $43-$ 60286.

603 Guillot, F. 1997. La grotta di Sant Elmo o" Grotta Verde" in Alghero. Revista de l'Alguer, 8(8), 81-92. 
Hijma, M., Engelhart, S. E., Törnqvist, T. E., Horton, B. P., Hu, P., Hill, D. F. 2015. A protocol for a geological sea-level database. Handbook of Sea-Level Research, edited by: Shennan, I., Long, AJ, and Horton, BP, Wiley Blackwell, 536-553.

Horton, B. P., Shennan, I. 2009. Compaction of Holocene strata and the implications for relative sealevel change on the east coast of England. Geology, 37(12), 1083-1086.

Kaniewski, D., Marriner, N., Morhange, C., Vacchi, M., Sarti, G., Rossi, V., Bini, M., Pasquinucci, M., Allinne, C., Otto, T. Luce, F., 2018. Holocene evolution of Portus Pisanus, the lost harbour of Pisa. Scientific reports, $8(1), 11625$.

Karkani, A., Evelpidou, N., Giaime, M., Marriner, N., Maroukian, H., Morhange, C. 2018. Late Holocene palaeogeographical evolution of Paroikia Bay (Paros Island, Greece). Comptes Rendus Geoscience, in press. doi.org/10.1016/j.crte.2018.04.004

Karkani, A., Evelpidou, N., Vacchi, M., Morhange, C., Tsukamoto, S., Frechen, M., Maroukian, H. 2017. Tracking shoreline evolution in central Cyclades (Greece) using beachrocks. Marine Geology 388, 25-37.

Kemp, A. C., Horton, B. P., Culver, S. J., Corbett, D. R., van de Plassche, O., Gehrels, W. R., Douglas, B.C., Parnell, A. C. 2009. Timing and magnitude of recent accelerated sea-level rise (North Carolina, United States). Geology, 37(11), 1035-1038.

Khan, N. S., Ashe, E., Horton, B. P., Dutton, A., Kopp, R. E., Brocard, G., Engelhart, S.E., Hill, F.F., Peltier, W.R., Vane, C.H., Scatena, F. N. 2017. Drivers of Holocene sea-level change in the Caribbean. Quaternary Science Reviews, 155, 13-36.

Khan, N. S., Ashe, E., Shaw, T. A., Vacchi, M., Walker, J., Peltier, W. R., Kopp, R.E., Horton, B. P. 2015. Holocene relative sea-level changes from near-, intermediate-, and far-field locations. Current Climate Change Reports, 1(4), 247-262.

Kopp, R. E., Simons, F. J., Mitrovica, J. X., Maloof, A. C., Oppenheimer, M. 2009. Probabilistic assessment of sea level during the last interglacial stage. Nature, 462(7275), 863-867.

Laborel, J., Morhange, C., Lafont, R., Le Campion, J., Laborel-Deguen, F., Sartoretto, S. 1994. Biological evidence of sea-level rise during the last 4500 years on the rocky coasts of continental southwestern France and Corsica. Marine Geology, 120(3-4), 203-223.

Lambeck, K., Antonioli, F., Anzidei, M., Ferranti, L., Leoni, G., Scicchitano, G., Silenzi, S. 2011. Sea level change along the Italian coast during the Holocene and projections for the future. Quaternary International, 232(1), 250-257.

Lambeck, K., Antonioli, F., Purcell, A., Silenzi, S. 2004. Sea-level change along the Italian coast for the past 10,000 yr. Quaternary Science Reviews, 23(14), 1567-1598. 

predictions for tectonically stable areas. Quaternary Science Reviews, 24(18), 1969-1988.

638 Lambeck, K., Rouby, H., Purcell, A., Sun, Y., Sambridge, M. 2014. Sea level and global ice volumes from the Last Glacial Maximum to the Holocene. Proceedings of the National Academy of Sciences, 111(43), 15296-15303.

641 Lambeck, K., Smither, C., Johnston, P. 1998. Sea-level change, glacial rebound and mantle viscosity 642 fornorthern Europe. Geophysical Journal International, 134(1), 102-144.

643 Lo Schiavo, F., 1987. Grotta Verde 1979: un contributo sul neolitico antico della Sardegna Atti della XXVI 644 Riunione Scientifica dell'Istituto Italiano di Preistoria e Protostoria, pp. 845-858

645 López-Merino, L., Colás-Ruiz, N. R., Adame, M. F., Serrano, O., Martínez Cortizas, A., \& Mateo, M. A. 646 2017. A six thousand-year record of climate and land-use change from Mediterranean seagrass mats. Journal 647 of Ecology 105, (5): 1267-1278.

648 Lorscheid, T., Stocchi, P., Casella, E., Gómez-Pujol, L., Vacchi, M., Mann, T., Rovere, A. 2017. Paleo sea649 level changes and relative sea-level indicators: Precise measurements, indicative meaning and glacial 650 isostatic adjustment perspectives from Mallorca (Western Mediterranean). Palaeogeography, 651 Palaeoclimatology, Palaeoecology, 473, 94-107.

652 Love, R., Milne, G. A., Tarasov, L., Engelhart, S. E., Hijma, M. P., Latychev, K., ... Törnqvist, T. E. 2016. 653 The contribution of glacial isostatic adjustment to projections of sea-level change along the Atlantic and Gulf 654 coasts of North America. Earth's Future, 4(10), 440-464.

Marco-Barba, J., Holmes, J. A., Mesquita-Joanes, F., Miracle, M. R. 2013. The influence of climate and sea656 level change on the Holocene evolution of a Mediterranean coastal lagoon: Evidence from ostracod palaeoecology and geochemistry. Geobios, 46(5), 409-421.

Marriner, N., Flaux, C., Morhange, C., Kaniewski, D. 2012a. Nile Delta's sinking past: Quantifiable links with Holocene compaction and climate-driven changes in sediment supply?. Geology, 40(12), 1083-1086. Marriner, N., Gambin, T., Djamali, M., Morhange, C., Spiteri, M. 2012b. Geoarchaeology of the Burmarrad ria and early Holocene human impacts in western Malta. Palaeogeography, Palaeoclimatology,

662 Palaeoecology, 339, 52-65.

663 Marriner, N., Morhange, C., Faivre, S., Flaux, C., Vacchi, M., Miko, S., Dumas, V., Boetto, G., Rossi, I. R. 664 2014. Post-Roman sea-level changes on Pag Island (Adriatic Sea): Dating Croatia's "enigmatic" coastal 665 notch?. Geomorphology, 221, 83-94.

666 Morhange, C., Marriner, N. 2015. Archeological and biological relative sea-level indicators. Handbook of 667 sea-level research, 146-156. 
Mastronuzzi, G., Sansò, P. 2002. Holocene uplift rates and historical rapid sea-level changes at the Gargano promontory, Italy. Journal of Quaternary Science, 17(5-6), 593-606.

Mauz, B., Vacchi, M., Green, A., Hoffmann, G., Cooper, A. 2015. Beachrock: a tool for reconstructing relative sea level in the far-field. Marine Geology, 362, 1-16.

Melis, R. T., Di Rita, F., French, C., Marriner, N., Montis, F., Serreli, G., Sulas, F., Vacchi, M. 2018. 8000 years of coastal changes on a western Mediterranean island: A multiproxy approach from the Posada plain of Sardinia. Marine Geology 403, 93-108.

Melis, R. T., Depalmas, A., Di Rita, F., Montis, F., Vacchi, M. 2017. Mid to late Holocene environmental changes along the coast of western Sardinia (Mediterranean Sea). Global and Planetary Change. 155, 29-41.

Milne, G. A., Gehrels, W. R., Hughes, C. W., Tamisiea, M. E. 2009. Identifying the causes of sea-level change. Nature Geoscience, 2(7), 471-478.

Milne, G., Mitrovica, J., 1998. Postglacial sea-level change on a rotating Earth. Geophysical Journal International $133(1), 1-19$.

Milne, G.A., Long, A.J., Bassett, S.E., 2005. Modeling Holocene relative sea-level observations from the Caribbean and South America. Quaternary Science Reviews 24, 1183-1202.

Mitrovica, J.X., Milne, G.A., 2003. On postglacial sea level: I. General Theory. Geophysical Journal International, 154 (2), 253-267.

Nesteroff, W. D. 1984. Étude de quelques grès de plage du sud de la Corse: datations 14C et implications néotectoniques pour le bloc corso-sarde. Travaux de la Maison de l'Orient, 8(1), 99-111.

Nicholls, R. J., Hanson, S. E., Lowe, J. A., Warrick, R. A., Lu, X., Long, A. J. 2014. Sea-level scenarios for evaluating coastal impacts. Wiley Interdisciplinary Reviews: Climate Change, 5(1), 129-150.

Nocquet, J. M. 2012. Present-day kinematics of the Mediterranean: A comprehensive overview of GPS results. Tectonophysics, 579, 220-242.

Olivera, C., Susagna, T., Roca, A., Goula, X. 1992. Seismicity of the Valencia trough and surrounding areas. Tectonophysics, 203(1-4), 99-109.

Orrù, P.E., Antonioli, F., Lambeck, K., Verrubbi, V. 2004. Holocene sea-level change in the Cagliari coastal plain (southern Sardinia, Italy). Quaternaria Nova

Orrù, P.E., Mastronuzzi, G., Deiana, G., Pignatelli, C., Piscitelli, A., Solinas, E., Spanu, P., Zucca, R. 2014. Sea level changes and geoarchaeology between the bay of Capo Malfatano and Piscinnì Bay (SW Sardinia) in the last 4 kys. Quaternary International 336, 180-189. 

Island, south-western Sardinia (Italy). Quaternary International 232(1), 71-81.

700 Palombo, M. R., Antonioli, F., Presti, V. L., Mannino, M. A., Melis, R. T., Orru, P., Stocchi, P., Talamo, S., 701 Quarta, G., Calcagnile, L., Deiana, G., Altamura, S. 2017. The late Pleistocene to Holocene 702 palaeogeographic evolution of the Porto Conte area: Clues for a better understanding of human colonization 703 of Sardinia and faunal dynamics during the last $30 \mathrm{ka}$. Quaternary International, 439, 117-140.

704 Pascucci, V., De Falco, G., Del Vais, C., Sanna, I., Melis, R. T., Andreucci, S. 2018. Climate changes and 705 human impact on the Mistras coastal barrier system (W Sardinia, Italy). Marine Geology, 395, 271-284.

706 Peltier, W. R. 2004. Global glacial isostasy and the surface of the ice-age Earth: the ICE-5G (VM2) model 707 and GRACE. Annual Review of Earth and Planetary Science, 32, 111-149.

708 Peltier, W., Argus, D., Drummond, R., 2015. Space geodesy constrains ice age terminal deglaciation: the 709 global ICE-6G_C (VM5a) model. Journal of Geophys. Research 120 (1), 450-487.

710 Pirazzoli, P. A. 2005. A review of possible eustatic, isostatic and tectonic contributions in eight late-

711 Holocene relative sea-level histories from the Mediterranean area. Quaternary Science Reviews, 24(18), 712 1989-2001.

713 Poher, Y., Ponel, P., Médail, F., Andrieu-Ponel, V., Guiter, F. 2017. Holocene environmental history of a 714 small Mediterranean island in response to sea-level changes, climate and human impact. Palaeogeography, 715 Palaeoclimatology, Palaeoecology, 465, 247-263.

716 Preuss, H., 1979. Progress in Computer Evaluation of Sea Level Data within the IGCP Project no. 61. Proc. 7171978 International Symposium of Coastal Evolution in the Quaternary, pp. 104-134.

718 Primavera, M., Simone, O., Fiorentino, G., Caldara, M. 2011. The palaeoenvironmental study of the Alimini 719 Piccolo lake enables a reconstruction of Holocene sea-level changes in southeast Italy. The Holocene 21(4), $720 \quad 553-563$.

721 Purcell, A., Tregoning, P., Dehecq, A. 2016. An assessment of the ICE6G_C (VM5a) glacial isostatic 722 adjustment model. Journal of Geophysical Research: Solid Earth, 121(5), 3939-3950.

723 Reimer, P. J., Bard, E., Bayliss, A., Beck, J. W., Blackwell, P. G., Ramsey, C. B., ... Grootes, P. M. 2013. 724 IntCal13 and Marine13 radiocarbon age calibration curves 0-50,000 years cal BP. Radiocarbon, 55(4), 18697251887.

726 Reimer, P. J., Reimer, R. W. 2001. A marine reservoir correction database and on-line interface. 727 Radiocarbon, 43(2A), 461-463. 
Rodríguez-Pérez, A., Blázquez, A. M., Guillem, J., Usera, J. 2018. Maximum flood area during MIS 1 in the Almenara marshland (Western Mediterranean): Benthic foraminifera and sedimentary record. The Holocene, in press doi.org/10.1177/0959683618777069

731 Roqué Pau, C., Pallí Buxó, L. 1997. Depósitos litorales y variaciones del nivel del mar durante el Holoceno 732 en la Costa Brava (NE de Catalunya). Reunion del Cuaternario Ibérico: Asociación Española para el Estudio del Cuaternario [AEQUA]: 1997: Huelva, 1997, p. 178-183.

734 Rovere, A., Stocchi, P., Vacchi, M. 2016. Eustatic and relative sea level changes. Current Climate Change 735 Reports, 2(4), 221-231.

736 Rossi, V., Amorosi, A., Sarti, G., Potenza, M. 2011. Influence of inherited topography on the Holocene sedimentary evolution of coastal systems: an example from Arno coastal plain (Tuscany, Italy). Geomorphology, 135(1-2), 117-128.

Roy, K., Peltier, W. R. (2018). Relative sea level in the Western Mediterranean basin: A regional test of the ICE-7G_NA (VM7) model and a constraint on late Holocene Antarctic deglaciation. Quaternary Science Reviews, 183, 76-87.

Ruello, M. R., Cinque, A., Di Donato, V., Molisso, F., Terrasi, F., Ermolli, E. R. 2017. Interplay between sea level rise and tectonics in the Holocene evolution of the St. Eufemia Plain (Calabria, Italy). Journal of Coastal Conservation, 21(6), 903-915.

Ruiz, J. M., Carmona, P., Gomez-Bellard, C., van Dommelen, P. 2018. Geomorphology and environmental change around the Punic sites of the Terralba plain (Oristano Gulf, Sardinia, Italy). Boletin Geologico y Minero, 129(1-2), 331-351.

Sàbat, F., Gelabert, B., Rodríguez-Perea, A., Giménez, J. 2011. Geological structure and evolution of Majorca: Implications for the origin of the Western Mediterranean. Tectonophysics, 510(1), 217-238.

Sabatier, P., Dezileau, L., Colin, C., Briqueu, L., Bouchette, F., Martinez, P., ... Von Grafenstein, U. 2012. 7000 years of paleostorm activity in the NW Mediterranean Sea in response to Holocene climate events.

752 Quaternary Research, 77(1), 1-11.

753 Salel, T., Bruneton, H., Lefèvre, D. 2016. Ostracods and environmental variability in lagoons and deltas 754 along the north-western Mediterranean coast (Gulf of Lions, France and Ebro delta, Spain). Revue de 755 Micropaléontologie, 59(4), 425-444.

756 Sander, L., Fruergaard, M., Koch, J., Johannessen, P. N., Pejrup, M. 2015. Sedimentary indications and 757 absolute chronology of Holocene relative sea-level changes retrieved from coastal lagoon deposits on Samsø, 758 Denmark. Boreas, 44(4), 706-720. 
Sander, L., Hede, M. U., Fruergaard, M., Nielsen, L., Clemmensen, L. B., Kroon, A., Johannessen, P.N., Nielsen, L.H., Pejrup, M. 2016. Coastal lagoons and beach ridges as complementary sedimentary archives for the reconstruction of Holocene relative sea-level changes. Terra Nova, 28(1), 43-49.

Scicchitano, G., Spampinato, C. R., Ferranti, L., Antonioli, F., Monaco, C., Capano, M., Lubritto, C. 2011. Uplifted Holocene shorelines at Capo Milazzo (NE Sicily, Italy): evidence of co-seismic and steady-state deformation. Quaternary International, 232(1), 201-213.

Serpelloni, E., Faccenna, C., Spada, G., Dong, D., Williams, S. D. 2013. Vertical GPS ground motion rates in the Euro-Mediterranean region: New evidence of velocity gradients at different spatial scales along the Nubia-Eurasia plate boundary. Journal of Geophysical Research: Solid Earth, 118(11), 6003-6024.

Serpelloni, E., Vannucci, G., Pondrelli, S., Argnani, A., Casula, G., Anzidei, M., Baldi., P., Gasperini, P. 2007. Kinematics of the Western Africa-Eurasia plate boundary from focal mechanisms and GPS data. Geophysical Journal International, 169(3), 1180-1200.

Shaw, T. A., Kirby, J. R., Holgate, S., Tutman, P., Plater, A. J. 2016. Contemporary salt-marsh foraminiferal distribution from the Adriatic coast of Croatia and its potential for sea-level studies. The Journal of Foraminiferal Research, 46(3), 314-332.

Shennan, I., Horton, B. 2002. Holocene land-and sea-level changes in Great Britain. Journal of Quaternary science, 17(5-6), 511-526.

Shennan, I., Long, A.J., Horton, B.P., 2015. Handbook of Sea-Level Research. John Wiley \& Sons

Somoza, L., Barnolas, A., Arasa, A., Maestro, A., Rees, J. G., Hernández-Molina, F. J. 1998. Architectural stacking patterns of the Ebro delta controlled by Holocene high-frequency eustatic fluctuations, delta-lobe switching and subsidence processes. Sedimentary Geology 117(1), 11-32.

Spada, G., Stocchi, P., 2007. SELEN: a Fortran 90 program for solving the "Sea Level Equation". Comput. Geosci. 33 (4), 538-562.

Spada, G., Antonioli, A., Cianetti, S., Giunchi, C. 2006. Glacial isostatic adjustment and relative sea-level changes: the role of lithospheric and upper mantle heterogeneities in a 3-D spherical Earth, Geophysical Journal International 165 (2), 692-702

Stiros, S. C., Laborel, J., Laborel-Deguen, F., Papageorgiou, S., Evin, J., Pirazzoli, P. A. 2000. Seismic coastal uplift in a region of subsidence: Holocene raised shorelines of Samos Island, Aegean Sea, Greece. Marine Geology, 170(1), 41-58.

Stocchi, P., Spada, G. 2007. Glacio and hydro-isostasy in the Mediterranean Sea: Clark s zones and role of remote ice sheets. Annals of Geophysics, 50(6). 
Stocchi, P., Spada, G. 2009. Influence of glacial isostatic adjustment upon current sea level variations in the Mediterranean. Tectonophysics, 474(1), 56-68.

792 Stocchi, P., Vacchi, M., Lorscheid, T., de Boer, B., Simms, A. R., van de Wal, R. S., Vermeesen, B.L.A., 793 Pappalardo, M., Rovere, A. 2018. MIS 5e relative sea-level changes in the Mediterranean Sea: Contribution 794 of isostatic disequilibrium. Quaternary Science Reviews, 185, 122-134.

795 Stuiver, M., Polach, H.A., 1977. Reporting 14C data. Radiocarbon 19, 355-363.

796 Tornqvist, T.E., Rosenheim, B.E., Hu, P., Fernandez, A.B., 2015. Radiocarbon dating and calibration. In: 797 Long, A.J., Horton, B.P. (Eds.), Shennan, I. Wiley, Handbook of Sea-level Research, pp. 349-360.

798 Tsimplis, M. N., Proctor, R., Flather, R. A. 1995. A two-dimensional tidal model for the Mediterranean Sea. 799 Journal of Geophysical Research: Oceans, 100(C8), 16223-16239.

800 Tuccimei, P., Soligo, M., Ginés, J., Ginés, A., Fornós, J., Kramers, J., Villa, I. M. 2010. Constraining 801 Holocene sea levels using U-Th ages of phreatic overgrowths on speleothems from coastal caves in Mallorca 802 (Western Mediterranean). Earth Surface Processes and Landforms, 35(7), 782-790.

803 Vacchi, M., Ghilardi, M., Spada, G., Currás, A., Robresco, S. 2017. New insights into the sea-level evolution 804 in Corsica (NW Mediterranean) since the late Neolithic. Journal of Archaeological Science: Reports, 12, $805782-793$.

806 Vacchi, M., Marriner, N., Morhange, C., Spada, G., Fontana, A., Rovere, A. 2016. Multiproxy assessment of 807 Holocene relative sea-level changes in the western Mediterranean: sea-level variability and improvements in 808 the definition of the isostatic signal. Earth-Science Reviews, 155, 172-197.

809 Vacchi, M., Rovere, A., Chatzipetros, A., Zouros, N., Firpo, M. 2014. An updated database of Holocene 810 relative sea level changes in NE Aegean Sea. Quaternary International, 328, 301-310.

811 Vacchi, M., Rovere, A., Zouros, N., Desruelles, S., Caron, V., Firpo, M. 2012. Spatial distribution of sea812 level markers on Lesvos Island (NE Aegean Sea): evidence of differential relative sea-level changes and the 813 neotectonic implications. Geomorphology, 159, 50-62.

814 van de Plassche, O., 1982. Sea-level change and water-level movements in the Netherlands during the 815 Holocene. Med. Rijks Geol. Dienst. 36, 1-93.

816 Vella, C., Fleury, T. J., Raccasi, G., Provansal, M., Sabatier, F., Bourcier, M. 2005. Evolution of the Rhône 817 delta plain in the Holocene. Marine Geology, 222, 235-265.

818 Vernant, P., Fadil, A., Mourabit, T., Ouazar, D., Koulali, A., Davila, J. M., Garate, J., McClusky, S., 819 Reilinger, R. 2010. Geodetic constraints on active tectonics of the Western Mediterranean: Implications for 820 the kinematics and dynamics of the Nubia-Eurasia plate boundary zone. Journal of Geodynamics, 49(3), $821 \quad 123-129$. 
Yll, R., Pantaleón-Cano, J., Pérez-Obiol, R.P., Roure, J. M. 1999. Cambio climático y transformación del medio durante el Holoceno en las Islas Baleares. Congrés del Neolític a la Península Ibérica, Saguntum Extra, 2, 45-51.

Figure captions

Figure 1. Spatial extent of the study area. Numbered rectangles denote the location of sea-level data for this study, grouped into five regions as explained in the text. Tectonic framework of the western Mediterranean. Faults are modified after Faccenna et al. (2014) and Vacchi et al. (2016).

Figure 2. A) Total plot of the 165 SLIPs used for the RSL reconstructions in the 5 regions. Red SLIPs represent those produced for the present database. Grey SLIPs are those included in the Vacchi et al. (2016) compilation. B) Stacked histogram of the SLIPs showing an increase in the number of SLIPs compared to the Vacchi et al. (2016) compilation.

Figure 3. RSL reconstructions in Catalonia (1), the Balearic Islands (2) and Gulf of Valencia (3) regions. SLIPs (boxes) are plotted as calibrated ages against change in sea level relative to present. Limiting points are plotted as terrestrial or marine horizontal lines. The dimensions of boxes and lines for each point are based on elevation and age errors. Black lines denote the geography of relative sea-level predictions calculated using SELEN and adopting the ICE-6G (VM5a) GIA model (see section 5). Pe: Pego; Va: Valencia; Am: Amenara; Ed: Ebro Delta; Cu: Cubelles; Ll: Llobregat Delta; Em: Empuries, Al: Alcudia; Gr: El Grau.

Figure 4. RSL reconstructions in northern Corsica (4) and Sardinia (5) regions. SLIPs (boxes) are plotted as calibrated ages against change in sea level relative to present. Limiting points are plotted as terrestrial or marine horizontal lines. The dimensions of boxes and lines for each point are based on elevation and age errors. Black lines denote the geography of relative sea-level predictions calculated using SELEN and adopting the ICE-6G (VM5a) GIA model (see section 5). Cc: Cap Corse; Cf: Cala Francese; Sc: Scandola; Sl: Sale lagoon; Sa: Sagone; Tg: Tanghiccia; Cv: Cavallo Island; Bs: Bonifacio Strait; Mj: Mignataghja; Ps: Posada; Ca: Capo Caccia; Cl: Cala Liberotto; Or: Gulf of Oristano; Tb: Terralba; At: Sant`Antioco; Mf: Capo Malfatano-Piscinni; Nr: Nora; Cg: Cagliari.

Figure 5. A) Top: 4th-order polynomial fits of the Balearics (blue, region 2) and Sardinia (red, region 5) SLIPs. Bottom: Difference between the two fitted RSL curves through time, in metres. B) GIA sea-level fingerprints for 2040-2050 relative to 1990-2000 in the Mediterranean Sea (modified from Galassi and 
858 Spada, 2014). Predictions were obtained by SELEN (Spada and Stocchi, 2007), using models ICE-5G

859 (VM2) (a, Peltier, 2004) and KL05 (b, Lambeck et al., 1998, Lambeck and Purcell, 2005).

860

861 Appendix A: SLIPs and limiting points included in the Relative Sea Level database. Latitude and Longitude 862 are expressed in decimal degrees.

863 
$-5^{\circ} \mathrm{E}$

$0^{\circ} \mathrm{E}$

$5^{\circ} \mathrm{E}$

$5^{\circ} \mathrm{E}$

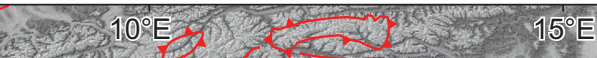
EURASIAN PLATE

France

$-45^{\circ} \mathrm{N}$

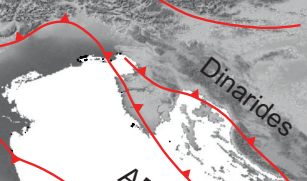

$+2 a^{2}=$

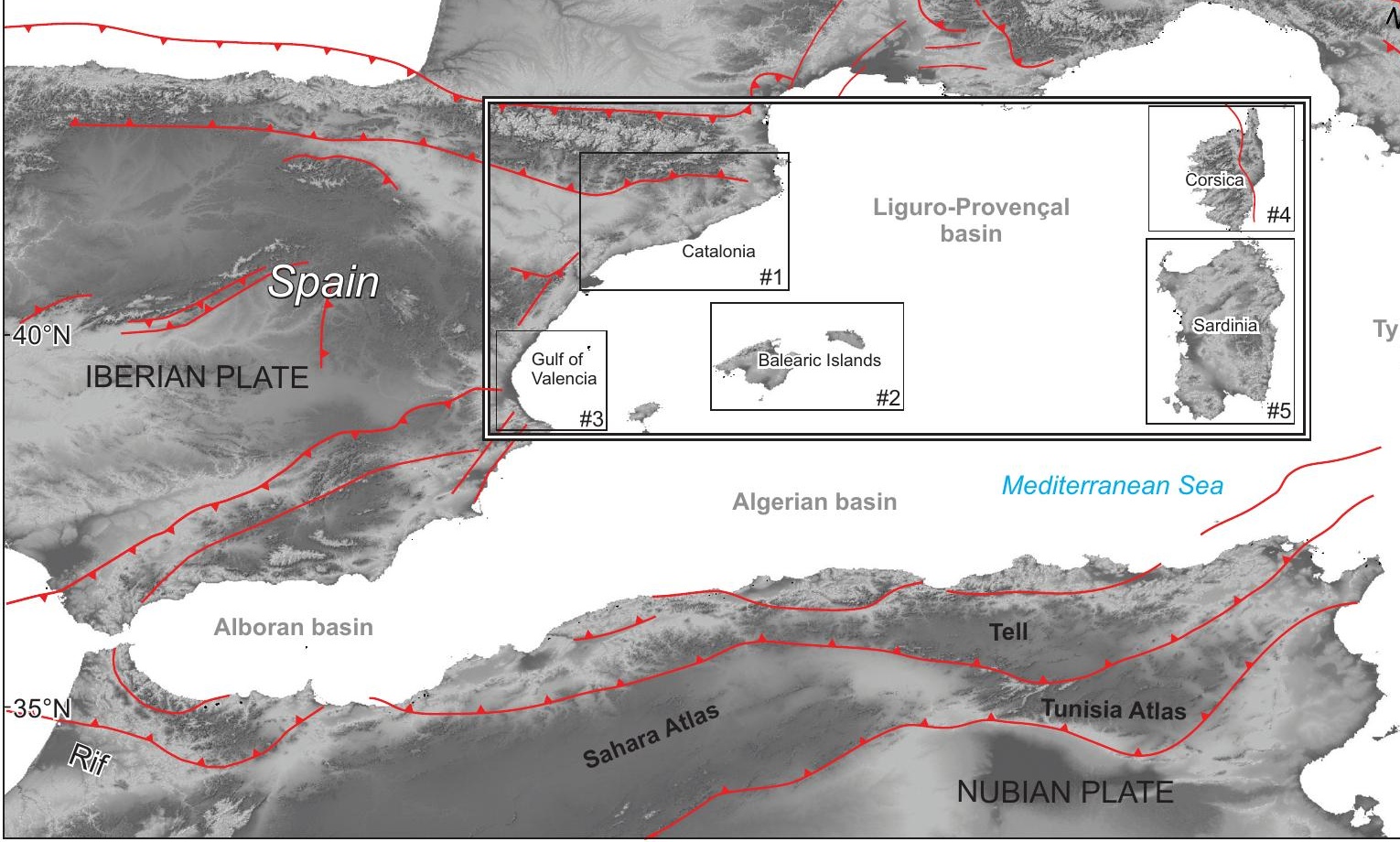

Pelagian block
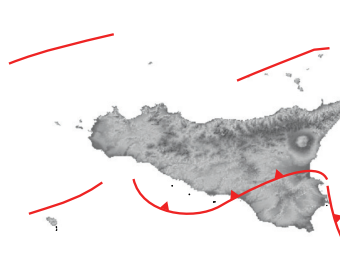

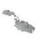

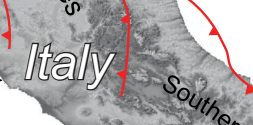

yrrhenian basin 


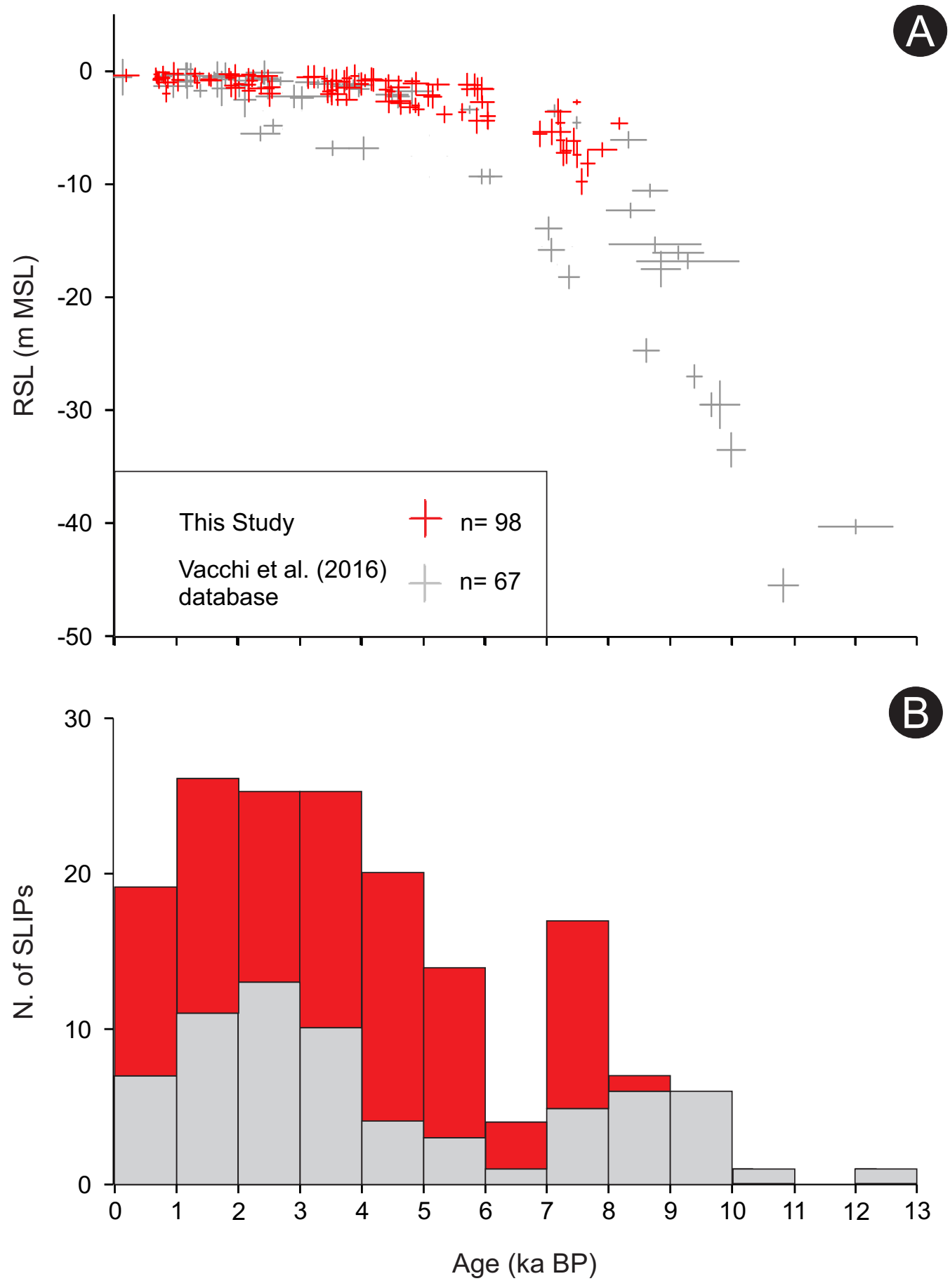




\section{Legend}

\begin{tabular}{l|l}
$\begin{array}{l}\text { New data } \\
\text { SLIPs }\end{array}$ & $\begin{array}{l}\text { Vacchi et al., 2016 } \\
\text { SLIPs } \\
\square \text { Basal }\end{array}$ \\
$\square$ Intercalated & $\square$ Basal \\
$\begin{array}{l}\square \text { Intercalated } \\
\square \text { Beachrocks }\end{array}$ & $\begin{array}{l}\text { L. byssoides } \\
\text { Limiting points } \\
\perp \text { Terrestrial }\end{array}$ \\
$\begin{array}{l}\text { Limiting points } \\
\text { Marine }\end{array}$ & $\perp$ Terrestrial \\
$\begin{array}{l}\text { RSL datapoint } \\
\text { location }\end{array}$ & $\bigcirc \begin{array}{l}\text { RSL datapoint } \\
\text { location }\end{array}$
\end{tabular}

$39^{\circ} \mathrm{N}$
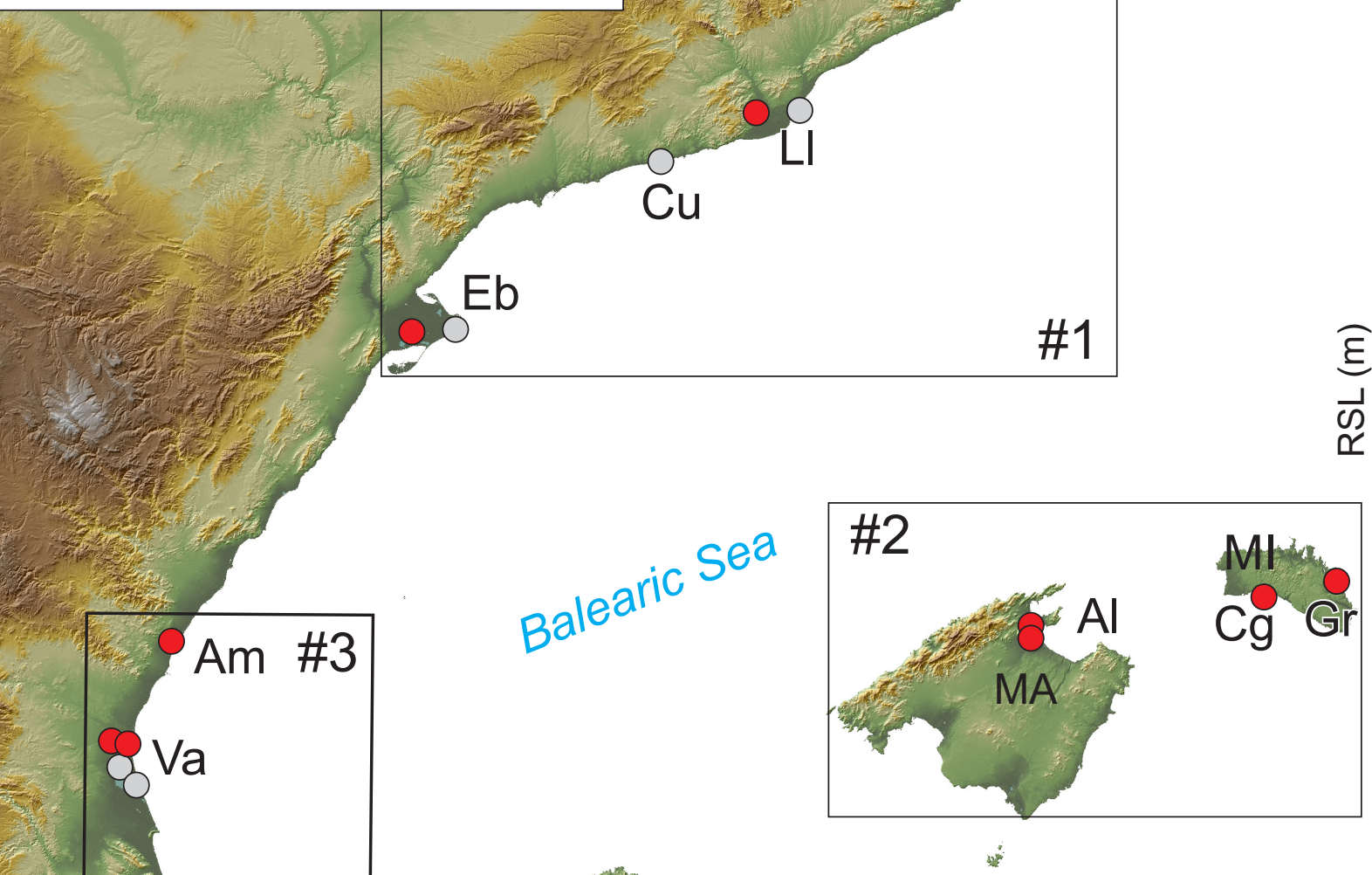

\#2

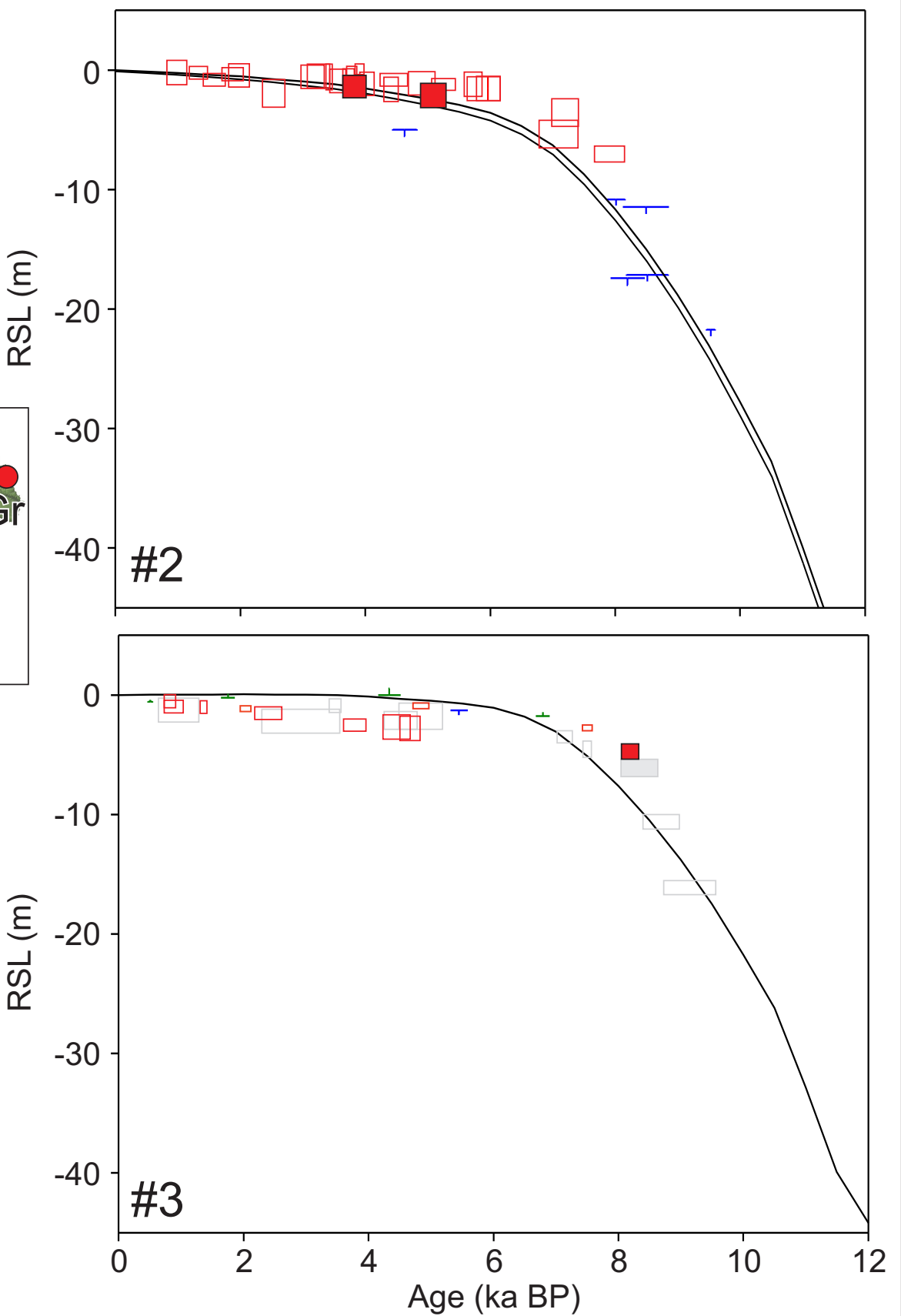




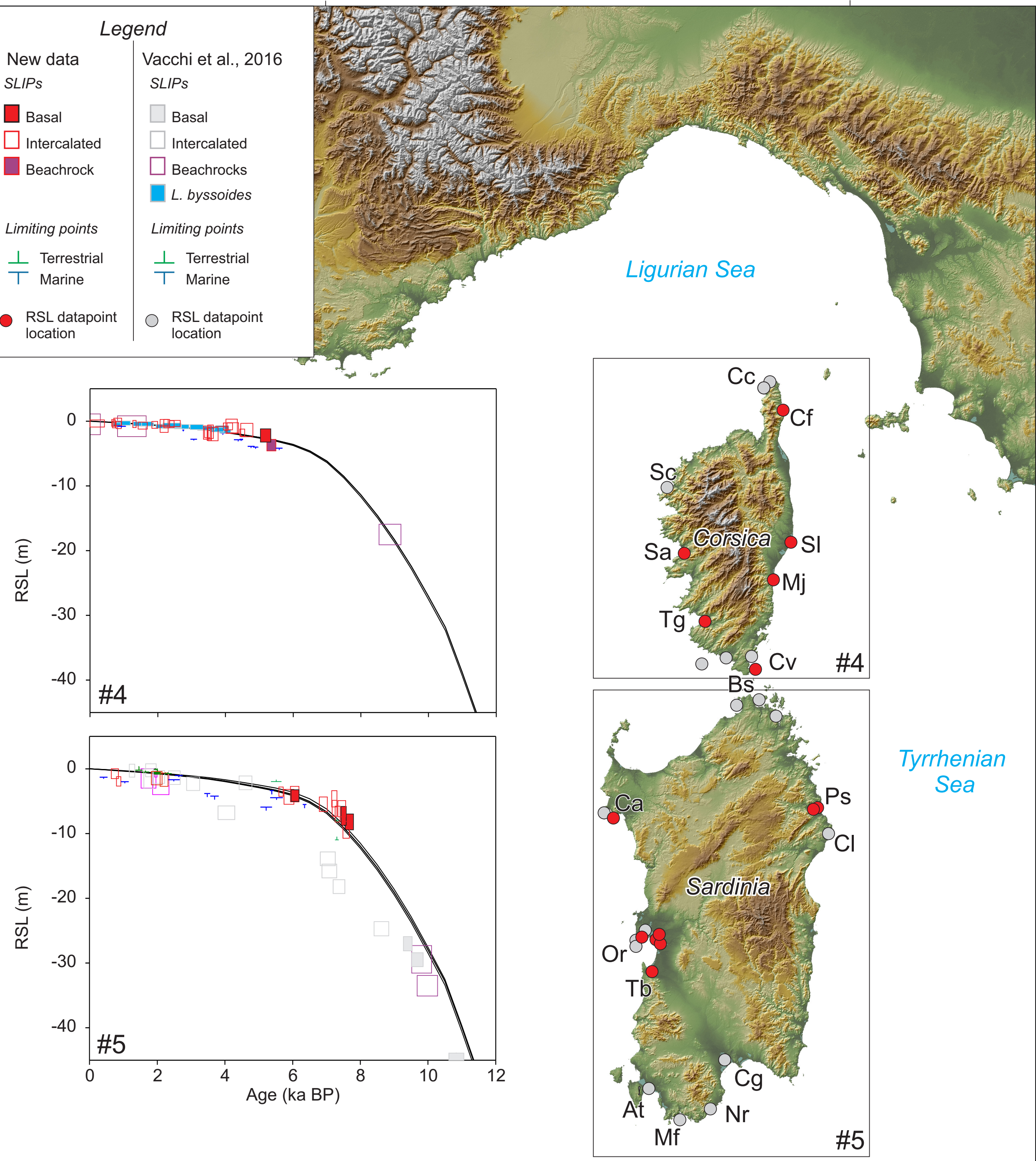




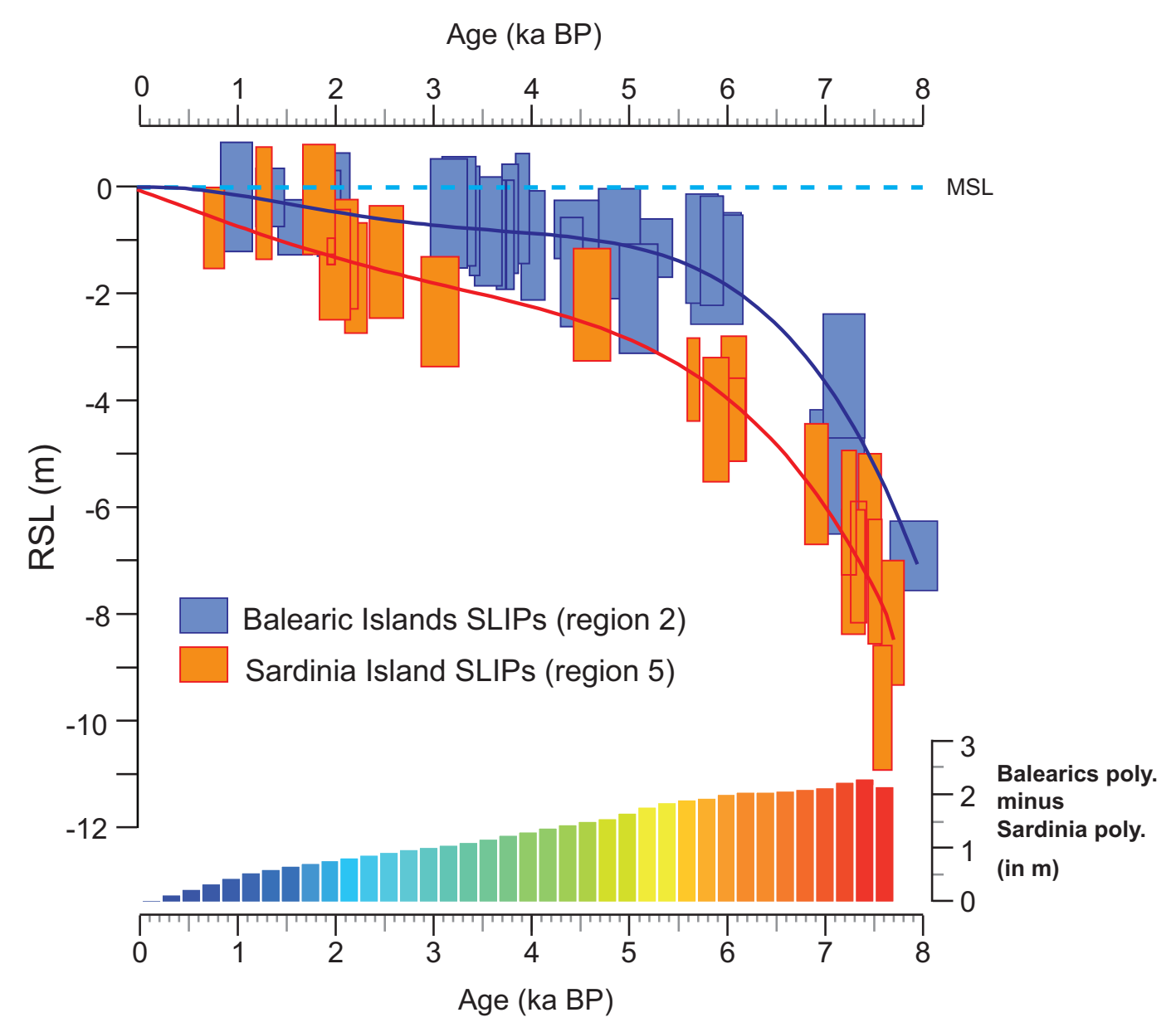

(a) ICE-5G (VM2)

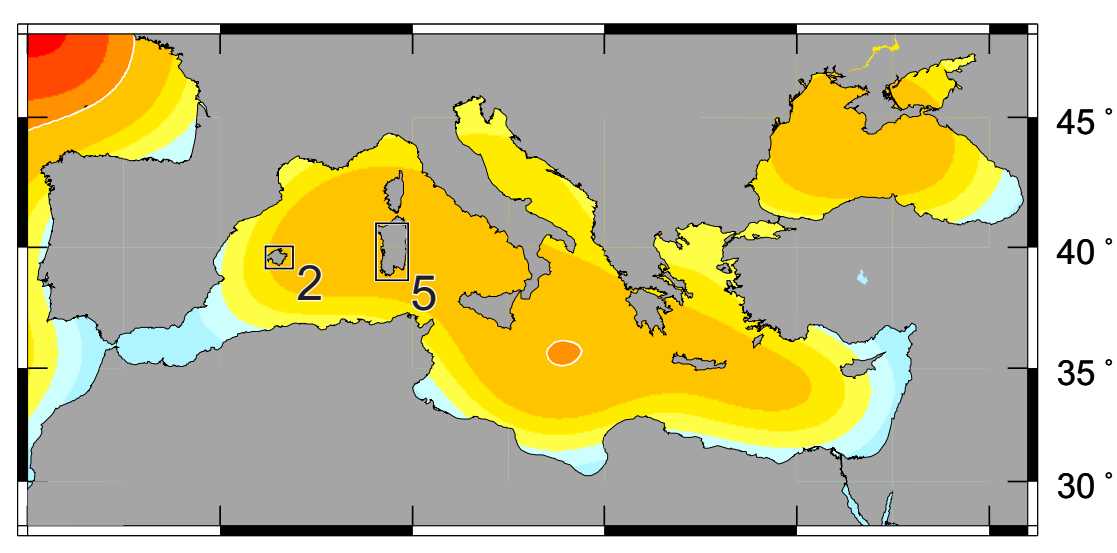

(b) KL05 (nominal)

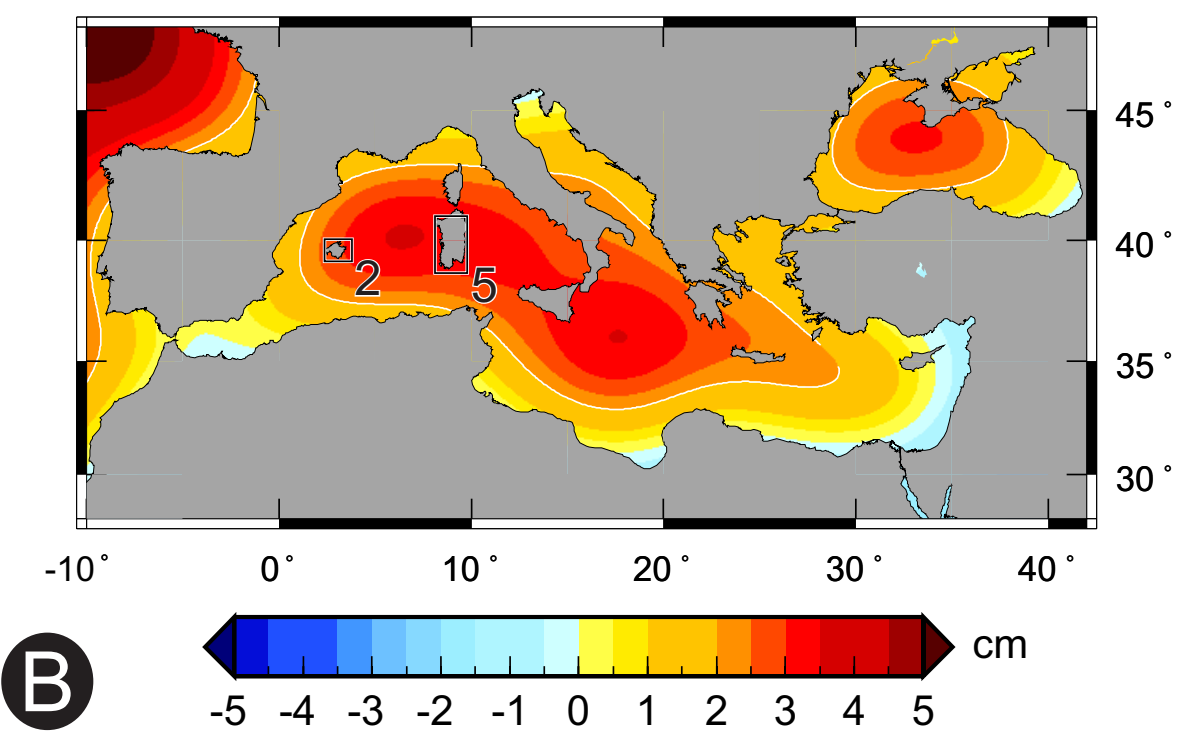


Table 1. Summary of the indicative meanings used to estimate the relative elevation of the sea-level index points (SLIPs) and limiting points for the database (see Vacchi et al., 2016 for the detailed facies descriptions). HAT: Highest Astronomical Tide; MHW: Mean High Water; MLW: Mean Low Water; MSL: Mean Sea Level. Note that the investigated coastal sectors have a lower microtidal regime. HAT values are equivalent to the Mean Highest High Water and typically do not exceed $0.05 \mathrm{~m}$ above MHW. Similarly, the Mean Lowest Low Water values are equivalent to the MLW.

\begin{tabular}{|c|c|c|c|}
\hline Sample Type & Evidence & Reference Water Level & Indicative Range \\
\hline \multicolumn{4}{|l|}{$\underline{\text { SLIPS }}$} \\
\hline $\begin{array}{l}\text { Lithophyllum } \\
\text { byssoides rim }\end{array}$ & $\begin{array}{l}\text { Identifiable in situ coralline rhodophyte Lithophyllum byssoides (formerly known as } \\
\text { Lithophyllum lichenoides) recognized at species level (Laborel et al. 1994; Faivre et } \\
\text { al., 2013). }\end{array}$ & $(\mathrm{HAT}$ to $\mathrm{MSL}) / 2$ & HAT to MSL \\
\hline Salt-marsh & $\begin{array}{l}\text { Salt-marsh plant macrofossils (e.g. Vella et al., 2005; Di Rita et al., 2010, Primavera et } \\
\text { al., 2011). Foraminiferal assemblages dominated by saltmarsh taxa (e.g., Caldara and } \\
\text { Simone, 2005; Shaw et al., 2016, Cearreta et al., 2016). }\end{array}$ & $(\mathrm{HAT}$ to $\mathrm{MSL}) / 2$ & HAT to MSL \\
\hline $\begin{array}{l}\text { Open or marine } \\
\text { influenced lagoon }\end{array}$ & $\begin{array}{l}\text { Macrofossil taxa dominated by marine brackish molluscs with the presence of } \\
\text { Cerastoderma glaucum, Bittium recticulatum often associated with Cerithium } \\
\text { vulgatum and Loripes lacteus (e.g. Di Rita et al., 2011; Giaime et al., 2017, Melis et } \\
\text { al., 2018). Foraminiferal and ostracods assemblages dominated dominated by marine } \\
\text { brackish littoral taxa or outer estuary taxa (e.g., Marriner et al., 2012b; Carmona et al., } \\
\text { 2016; Salel et al., 2016). Higher species diversity compared to the semi-enclosed } \\
\text { lagoon system. }\end{array}$ & $-1 \mathrm{~m}$ & MSL to $-2 \mathrm{~m}$ \\
\hline $\begin{array}{l}\text { Inner or semi } \\
\text { enclosed lagoon }\end{array}$ & $\begin{array}{l}\text { Macrofossil taxa dominated by brackish molluscs typical of sheltered marine- } \\
\text { lacustrine environments with the presence of Cerastoderma glaucum, Abra } \\
\text { segmentum, Hydrobbiidae spp. (e.g. Marriner et al., 2012b, Sabatier et al., 2012; } \\
\text { Ghilardi et al., 2017a,b;). Foraminifera and ostracod assemblages dominated by } \\
\text { brackish littoral taxa or inner estuarine taxa (Ejarque et al., 2016; Salel et al., 2016, } \\
\text { Cearreta et al., 2017). Lower species diversity compared to the open lagoon system. }\end{array}$ & $-0.5 \mathrm{~m}$ & MSL to $-1 \mathrm{~m}$ \\
\hline
\end{tabular}


$\begin{array}{ll}\begin{array}{l}\text { Undifferentiated } \\ \text { brackish }\end{array} & \begin{array}{l}\text { Foraminiferal, diatom and ostracod assemblages dominated by freshwater-slightly } \\ \text { brackish or swamp taxa and shallow marine taxa (e.g. Amorosi et al., 2013; Ghilardi et }\end{array} \\ \text { a } & \text { and }\end{array}$

brackish

(HAT to MLW)/2

HAT to MLW

environment

al., 2017a,b).

Beachrock with

cement fabric or

Samples showing intergranular intertidal cements (i.e., irregularly distributed needles

stratigraphic

information

micritic High-Mg Calcite cement e.g. Vacchi et al., 2012; Mauz et al., 2015)

\section{General}

Samples that do not meet the above requirements for a classification as intertidal

beachrock

beachrocks (e.g., Vacchi et al., 2016)

-1 to $+2 \mathrm{~m}$ MSL

\section{Limiting Points}

Identifiable marine shells in poorly to well-bedded sandy and silty sediments typical of the upper shoreface or prodelta environments (e.g., Sabatier et al., 2012; Marriner et

Marine limiting

al., 2012b). Posidonia oceanica beds found in inner bay and shoreface marine deposits (Vacchi et al., 2017; Pascucci et al., 2018). Foraminiferal and ostracod assemblages dominated by marine taxa (Carboni et al., 2002; Rossi et al., 2011 ; Amorosi et al., 2013, Salel et al., 2017).

Freshwater plant macrofossils and peat with freshwater diatoms (e.g. Di Rita et al., 2010; Melis et al., 2016). Upper beach/foreshore deposits and terrestrial paleosoils.

Terrestrial

Foraminiferal and ostracod assemblages dominated by freshwater taxa in swamps or 